\title{
Corpus based study of verbs explain and clarify as an example of assistance in pedagogical settings
}

\author{
Maja Séguin \\ Evangelical Theological Seminary, Osijek, Croatia
}

\begin{abstract}
The use of synonymy and near-synonymy allows us to differently express similar ideas and meanings, as well as perspectives. However, their use and nuances may be unclear to language learners, such as the selected case of the verbs explain and clarify. This paper examines the usage of the two verbs by looking into corpus data and uses Sinclair's methodological procedure as an alternative to dictionary references. Also included is a discussion of aspects and criticisms of corpus linguistics, mentions (and uses of) computer technologies for the analysis of language by discovering usage patterns, significant exceptions and semantic prosody, and exploring whether using corpora in the classroom would be beneficial to language learners.

Key words: synonym; near-synonymy; corpus; corpus linguistics; British National Corpus (BNC); Google Books corpus.
\end{abstract}

\section{Introduction}

When using language, we face the possibility of expressing ourselves in different ways but portraying the same or similar meaning. Synonymy and near-synonymy are communicative tools which allow for the presentation of alternate perspectives of the same idea (Divjak, 2010:2). They are different words, belonging to the same part of speech, which can be used in various contexts, leaving the meaning of the sentence intact. To understand the shades of meaning similar lexemes produce, as well as to make appropriate communicative choices and to help language learners, further investigations into usage of similar-in-meaning words should be conducted. This paper examines the usage of two synonymous verbs, explain and clarify after noticing several EFL students using the terms interchangeably in an academic context and ignoring the potential for nuances that could exist. This analysis of the two verbs is intended to serve as an example of the analysis a language learner could apply to gain a deeper understanding of which (near-)synonym is most appropriate for a given context. 
Corpora are used for distributional and collocational patterns, seeking meaning and frequency differences in various contexts, to suggest accurate selection when communicating, as well as to elicit implications for language instruction. The chosen verbs share the same basic dictionary definition, "to make clearer or easier to understand" (Cambridge Advanced Learner's Dictionary, 2005; The American Heritage English as a Second Language Dictionary, 1998; Longman Dictionary of American English, 1983), but their usage seems to differ when it comes to what can be clarified or explained (e.g. clarify cannot replace explain in explain your blackened eye, explain your noisy behavior). Insight into corpus data provides more information on tendencies than looking up the definition in dictionaries that can help non-native speakers.

This paper starts by presenting the theory used in section 2 . The general steps of the analytical methodology used form section 3 . Section 4 combines the results of the analysis with discussion. The conclusion in section 5 summarizes findings as to the finer aspects of the usage of the two verbs.

\section{Theory}

This literature review summarizes definitions and previous works on synonyms, corpus linguistics, collocates and colligates, pedagogical aspects and Sinclair's methodological procedure as used in this paper.

\subsection{Synonyms}

Perfect synonyms are words that convey identical meaning (Taylor, 2002: 265 ) and could thus be used interchangeably. Some consider such words to be rare while others question if these exist in this absolute sense (Inkpen \& Hirst, 2006: 223). If this is true, then dictionaries of synonyms are actually lists of near-synonyms. Near-synonyms are words that have a highly similar, not identical, meaning and "a low degree of implicit contrastiveness" (Cruse, 1986:266), that is, they do not tend to exclude one another, such as warm and hot might (Taylor, 2002: 266).

The choice of near-synonym will depend "on the context and on the nuances that need to be conveyed" (Inkpen \& Hirst, 2006: 224). While some (Divjak, 2008: 22) look for objective means to determine if words are nearsynonyms, this paper remains on the level of introspection that a teacher of English as Second Language could rely on in a classroom setting. 


\subsection{Corpus}

Texts making up a corpus, chosen by external criteria, are pieces of language meant to represent language variety (Sinclair, 2005a), as well as choices and competence of the language users documented in texts, but also the impact of social circumstance on communicative patterns (Andersen, 2010: 548). Computer technology has allowed extensive and rapid analysis of language use by handling large collections of texts as well as more easily identifying linguistic features such as "association patterns" (Biber et al, 2000: 4) and repetitions (Hunston, 2002: 123). It is concerned with frequent and typical occurrences in language, as well as relations between instances and norms (Stubbs, 2001: 151).

Scholars believe a corpus gives an insight into language and believe it to be a reliable guide as opposed to using native speaker intuition (Hunston, 2002: 20). Hunston states that corpora 'lead to new descriptions of a language,' and as such can assist in pedagogical settings when making teaching materials, syllabus and revising methodological approaches (Hunston, 2002: 137).

Although corpus linguistics has become a crucial methodological tool extensively accepted in the field (McEnery \& Hardie, 2012: 226), the creation and use of corpora have provoked criticism and "Mount Everest questions" (Biber \& Finegan, 1991: 205), as well as differing opinions on the usefulness of corpora even among the advocates (McEnery et al, 2006: 131). Widdowson (2000: 6) points out that corpus linguistics does not provide an insight into the language users or a measure of their competence, as it only displays textual instances of meaning-making, lacking the complexity of other linguistic, non-linguistic and contextual factors. Additionally, he notes that it lacks a defined pedagogical approach to be appropriate for classroom use. As it is, corpora reflect decontextualized language, which should be contextually made appropriate for learners to consider it real and motivating (Widdowson, 2000: 7). This individual subjectivist approach, stressing the importance of learning language through dialogue and context, sees an issue of missing out the elements critical to meaning which may not be reproduced in quantitative evaluations, questioning the learning outcomes from words that are removed from their context and whose meaning is constantly evolving. Another criticism involves the danger of using corpora by focusing on "surface forms" (Ädel, 2010: 49), only the word or phrase, which then the analyst needs to connect to meaning presuming s/he holds the knowledge and views language objectively. Some have raised the question of incompleteness of computer corpora, indicating that there may be words or phrases that are imaginable and possible, but not recorded in the corpus (Flowerdew, 2011: 32). Hunston (2002: 160) also explains the difficulty of compiling, and therefore using, comparable corpora when there 
is no access to older texts. Besides the problem of representativity, Emons (1997: 66) sees a problem with grammatical mistakes potentially interpreted as the dialectics of variants of native speakers or not detected at all by corpus linguistic methods. When it comes to spelling variations, analysts face difficulties in the frequency and collocation calculations (Hunston, 2002: 160).

Regardless of debates and skepticism, use of corpora can be considered as a generally accepted and important linguistic tool as evidenced by its rapid development in semantic research (Glynn, 2014: 1) and fast growth as a methodological discipline in linguistics generally (Gries, 2015: 1). Sinclair (2005b: 101) warns "to avoid perfectionism," as there is no ideal corpus and "the results of corpus research so far are indicative of patterns and trends, of core structures and likely contributions to theory and description, but they are not yet definitive." The benefit of a corpus usually depends on the researcher's intent, and as corpora do not inevitably provide descriptions, the analyst is there to draw explanations. Researchers' task is to notice repetitions as well as implicit meaning, using methodologies that need to be explained by steps found between observation and interpretation (Hunston, 2002: 123). And yet, the ideal text analysis system would be completely automated, consisting of both linguistic and non-linguistic knowledge of a native speaker (Bell, 1991: 296).

\subsection{Collocates and colligation}

Corpus has shown itself crucial in statistically measuring collocations, or tendencies of lexical words to co-occur. Observing the frequencies, noticing the regularities and comparing the co-occurrences is a part of the methodology. The observed data can provide information on noticeable concepts, such as change in frequency, differences and change in language use (Hunston, 2002: 120). Collocations can also identify lexical sets (Halliday, 1966: 156). For a reliable measure of collocation, it is not sufficient to know an absolute count, as much as there needs to be evidence for certainty of cooccurrence (Hunston, 2002: 72). This evidence is provided by statistical calculations or association measures (AMs) including commonly used methods such as log-likelihood, Mutual Information, t-score, and others (Gries, 2015: 95). While the use of such AMs may lead to a skewing of results and other problems, for example if dealing with sequences of words (Gries, 2015: 95), it can also be successful under certain circumstances such as if working with higher frequencies (Gries, 2015: 105). While a list of collocates by itself cannot show the association to meaning, necessary interpretation can reveal attitudes (Hunston, 2002: 120).

Colligation is the relation between words at the grammatical level, such 
as co-occurrence of a word or phrase with grammatical classes or grammatical words (McEnery et al, 2006: 11). It is harder to identify colligation than collocation in a corpus that has not added grammatical or "part of speech" (POS) tagging although this can be added to an untagged text by tools using sophisticated statistical models and other rules to "achieve fairly accurate tagging" (Rayson et al, 2007: 2). These lexical and grammatical elements are crucial for analyzing the meaning of a word that co-occurs with them (Sinclair, 1991: 108).

\subsection{Semantic preference, semantic prosody, frequency distribution}

As collocations give an insight into attraction between specific word forms, colligation into co-occurring grammatical classes, semantic preference shows textual coherence by observing collocate lists for attraction between words and certain semantic fields (Stubbs, 2009: 125).

Stubbs, using phrasal verbs (1995: 2) also presents Sinclair's observation that there are words that co-occur with other words creating negative or positive meaning, calling this collocational phenomenon 'semantic prosody.' This refers to the phenomenon of a word or a phrase adopting the connotation of its setting carrying a hidden message or attitude (Hunston, 2002: 141). It represents the motivation and it is often not retrievable from conscious knowledge.

Hunston (2002: 161-163) notes how distribution, the uneven frequency of many words across registers and grammatical features including verb forms, can indicate different meanings. For example, negative forms and the present tense occur more frequently in conversations than in written academic prose, the past tense more in fiction, infinitive patterns more in expository prose and fiction than in conversation.

Stubbs (2001: 153) states that the impact of the previously mentioned semantic patterns must be further explored as individual speakers do not control them. However, they are interrelated and have an effect and influence on linguistic features and preferences.

\subsection{Pedagogical aspects}

While corpora can be used indirectly in the process of creating educational materials, it is also possible to have learners use the material directly (Corino \& Onesti, 2019: 2). Data driven learning (DDL), used to refer to the application of tools of corpus linguistics by language learners, has "every student a Sherlock Holmes" (Johns, 1991 in Corino \& Onesti, 2019: 2). In such cases, learners are guided to query corpora for the purpose of learning 
or as a reference resource (Cobb \& Boulton, 2015: 480).

Although "quite demanding on the learner" (ibid), it has been stated that this helps students learn language in context, increases their autonomy and equips them with a number of skills (Gilquin \& Granger, 2010: 1). Studies have shown that DDL and corpora usage generally show large positive effects (Boulton \& Cobb, 2017: 378). Learners' direct use of computer technologies over the usage of handouts has shown even greater effects (Boulton \& Cobb, 2017: 372).

\subsection{Sinclair's corpus analysis and patterns}

Identifying patterns in text usage is done by looking for words and structures frequently occurring together and defining a meaning (Hunston \& Francis, 2000: 37). Latent patterns, as referred to by Sinclair and Coulthard, are patterns that "tend to remain unobserved when the same words or phrases are met in their normal contexts" (Hunston, 2002: 9). Sinclair (2004: 17-18) describes six types of patterns. He considers patterns based on variations of a lemma ('move' vs 'moving') and of word class ('combat' as noun vs verb), "privileges of occurrence or restrictions in group structures" (Sinclair, 2004: 18) and traditional categories (for example when 'of' is used as preposition). Finally, there are subliminal "aura of meaning" (ibid) patterns (such as 'set in' tending to present negative situations such as bad weather) and there are collocations. He (2004: 10) also cautions regarding theories related to patterned data, that "prioritizing some patterns" (ibid) could obscure others. Corpus Pattern Analysis (CPA) considers that patterns are not likely to lead to an understanding of meaning if verbs and nouns are taken as words in isolation (Hanks, 2004: 88). Rather, the analysis of words in the context of lexical sets can reduce the confusion for non-native speakers (Hanks, 2004: 91).

It has been argued (McEnery et al, 2006: 147) that Sinclair's corpus analysis provides a method. Stubbs (2009: 115) summarizes Sinclair's method of analysis as searching for patterning across large collections of long and authentic texts using computer technology. Such technology uses quantitative, observational techniques. Concordance analysis is of special interest as it is the most familiar of all corpus linguistic methods and is useful in investigations of individual word-forms. Sinclair (2003: xvi-xvii) describes his procedure as following a number of steps: initiate (identify first patterns from repeated words or grammatical word classes), interpret (form a hypothesis for the pattern), consolidate (gather additional evidence), report (write out the hypothesis), recycle (find additional patterns), result (list all hypothesis), and repeat (look at another sample).

Sinclair (ibid) considers it unwise to analyze all instances if there is a 
larger number of results and that computers should do the "routine work" even if software cannot take over and "complete an exhaustive description of your data" (2003: xviii). Sinclair has no explicit step applying searches against the complete corpus. While a few lines may prove a pattern exists, it will not show statistical relevance.

\section{Methodology}

The primary corpus used in this paper is the 100 million-word British National Corpus (BNC) composed of $90 \%$ written and $10 \%$ spoken language samples, and consisting of various registers and contexts. Analysis was performed using the BNCweb tool hosted by Lancaster University.

The Google Books corpus with 361 billion words (Michel et al, 2011: 176) was used for a high-level overview of the popularity of the terms through time. To have a better comparison to the BNC results, the British English subset was chosen. Although the Google Books corpus is larger, the inability to see words in context and general tooling limited it to this secondary role.

The first step was to obtain a general picture of the usage of the two verbs, using the Google Corpus n-gram viewer, giving the relative frequency through time and BNCweb's distribution function across different metadata categories and sub-corpora.

The second step was to find patterns for the verb clarify regardless of tense. This followed Sinclair's model for discovering usage patterns, with 100 random lines as the sample, but focusing on patterns that could help define what is the object of the verb. Possible patterns in the sample were identified as individual hypotheses for further investigation. Where Sinclair's 'reporting' step calls for an "explicit, testable version" of each hypothesis, search queries matching the patterns were defined to verify patterns' relevance compared to all uses of the verb in the corpus. Finally, as an extension of Sinclair's process, collocations from the corpus were retrieved to see if there are significant exceptions.

During this step, identification of patterns within the sample relied on human observation, while counts for collocations and colligations were retrieved through $\mathrm{BNCweb}$ tooling. While identifying patterns, possible semantic prosodies were noted. When working with the small samples, the results were ordered based on raw frequency. When working with the full corpus, log-likelihood was used primarily to verify statistical relevance, while Mutual Information (MI) was used for additional validation.

The third step was to find patterns for the verb explain compared with clarify. This was mainly a repetition of the second step but for the verb explain regardless of tense. Before looking for new patterns however, those 
Maja Séguin: Corpus based study of verby explain and clarify as an example of assistance in pedagogical settings

that existed for clarify were examined if also relevant for explain.

\section{Results and patterns}

Following the steps outlined in the methodology, results are presented and discussed. In this section, 'popularity' is used to represent the relative frequency per million words and 'sample' refers to the 100 lines retrieved for each verb (see appendix 1 and 2). References to individual results in the samples are put in square brackets, with the result number prefixed by a $\mathrm{C}$ or E referring to clarify and explain respectively (ex: [C1], [E99]).

\subsection{General usage of the verbs}

The Google Books (British English) corpus shows that the usage of explain was roughly ten times more popular than clarify around the year 2000. Both words have had their relative usage increase in the last century: explain by over $50 \%$, clarify by over $1000 \%$. The change in popularity of the words over time does not bias the further results considering the BNC's focus on the late twentieth century (BNC 2007) where the ratios were more stable.

\section{Google Books Ngram Viewer}

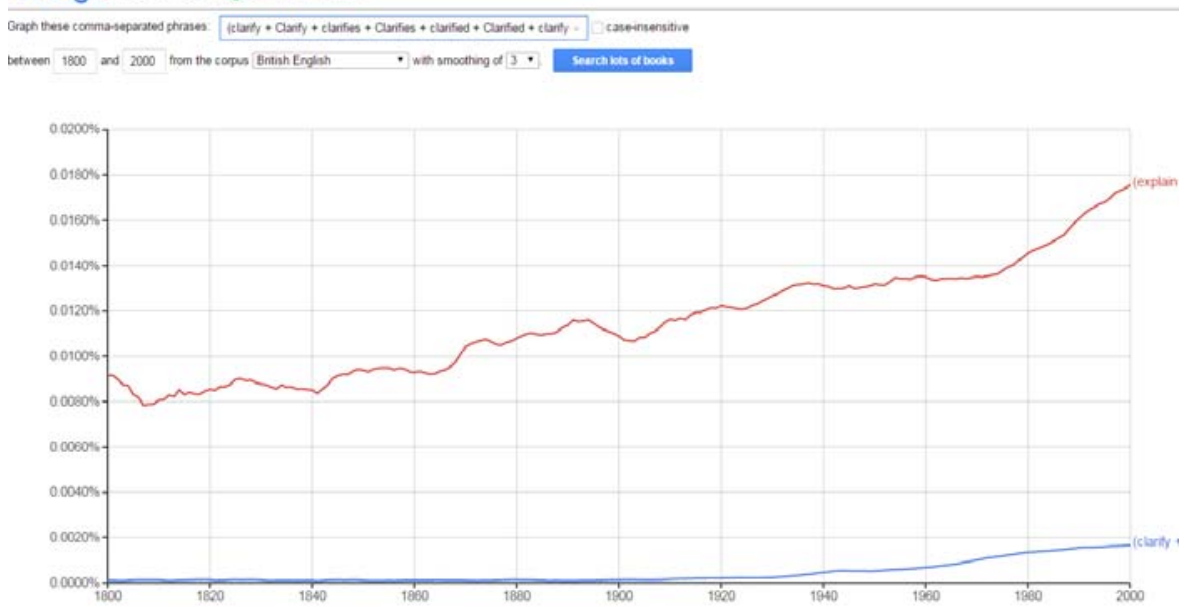

Figure 1: Graph of relative usage of explain (red) and clarify (blue)

Statistics from BNC's distribution function show more detailed information. Overall, the verb explain (in all forms) occurs 18651 times (relative frequency: 189,71 times per million words), while clarify occurs only 1435 times (14,6 times per million words), 13 times less.

Of the distribution across various types of written texts (Table 1), both 
Maja Séguin: Corpus based study of verby explain and clarify as an example of assistance in pedagogical settings

words are most popular in academic prose. The distribution between fiction and verse shows a contrast, this has the second highest popularity for explain, having nearly the same rate as for academic prose, while this is the second least likely place to find the verb clarify, over seven times less than academic prose. The reason for this contrast becomes clearer from further searches into the corpus and is visible in results presented later.

Table 1: Distribution by type of written text (relative frequency per million words)

\begin{tabular}{|l|c|c|}
\hline Type of text & \{clarify/V & $\{$ explain/V \\
\hline Academic prose & 28.96 & 280.2 \\
\hline Fiction and verse & 3.72 & 224.23 \\
\hline Newspapers & 8.29 & 142.37 \\
\hline Non-academic prose and biography & 16.38 & 188.43 \\
\hline Other published written material & 12.11 & 162.24 \\
\hline Other spoken material & 26.07 & 148.32 \\
\hline Spoken conversation & 1.42 & 48.65 \\
\hline Unpublished written material & 13.43 & 153.15 \\
\hline
\end{tabular}

A gender bias can be observed in the usage of clarify while not so with explain (

Table 2). Reasons for this were not immediately apparent nor further explored. The relative frequency of the two verbs per authors' age groups (

Table 3) reinforces that explain is a common word and thus used and known at a young age, while clarify is rarer.

Table 2: Distribution by gender of author of written text (relative frequency per million words)

\begin{tabular}{|l|c|c|}
\hline Gender & $\{$ clarify/V\} & $\{$ explain/V \\
\hline Male & 28.96 & 280.2 \\
\hline Female & 3.72 & 224.23 \\
\hline Mixed & 8.29 & 142.37 \\
\hline
\end{tabular}

Table 3: Distribution by age-group of author of written text (relative frequency per million words) 
Maja Séguin: Corpus based study of verby explain and clarify as an example of assistance in pedagogical settings

\begin{tabular}{|c|c|c|}
\hline Age group & $\{$ clarify/V $\}$ & $\{$ explain/V $\}$ \\
\hline $0-14$ & 0 & 167.9 \\
\hline $15-24$ & 3.69 & 224.85 \\
\hline $25-34$ & 10.59 & 213.5 \\
\hline $35-44$ & 10.59 & 220.61 \\
\hline $45-59$ & 10.1 & 210.91 \\
\hline $60+$ & 9.17 & 190.78 \\
\hline
\end{tabular}

The popularity of the verbs between written and spoken texts (Table 4) shows different tendencies: clarify has a similar popularity, while explain is nearly twice as popular in the written than in the spoken form. A similar gender bias (Table 5) as for written texts is visible for the spoken texts for clarify, while an unexpected gender bias is found with explain, where it is used nearly twice as often. The age distribution shows a tendency that middle age groups use these verbs the most (Table 6).

Table 4: Distribution by type of text (relative frequency per million words)

\begin{tabular}{|c|c|c|}
\hline Type of text & \{clarify/V\} & $\{$ explain/V $\}$ \\
\hline Written & 14.42 & 199.41 \\
\hline Spoken & 16.04 & 107.78 \\
\hline Overall & $\mathbf{1 4 . 6}$ & $\mathbf{1 8 9 . 7 1}$ \\
\hline
\end{tabular}

Table 5: Distribution by speaker in spoken texts (relative frequency per million words)

\begin{tabular}{|c|c|c|}
\hline Gender & \{clarify/V\} & $\{$ explain/V $\}$ \\
\hline Male & 14.95 & 126.47 \\
\hline Female & 10.94 & 71.11 \\
\hline
\end{tabular}

Table 6: Distribution by age-group of the speaker in spoken texts (relative frequency per million words)

\begin{tabular}{|c|c|c|}
\hline Age group & \{clarify/V & $\{$ explain/V \\
\hline $0-14$ & 0 & 33.75 \\
\hline $15-24$ & 0 & 65.61 \\
\hline $25-34$ & 11.6 & 102.63 \\
\hline $35-44$ & 20.45 & 80.87 \\
\hline $45-59$ & 16.48 & 167.24 \\
\hline $60+$ & 0.88 & 28.13 \\
\hline
\end{tabular}

The general information collected from the corpus does not answer the questions about usage, although it raises some questions. The first is why would 'explain', compared to 'clarify', be so much more popular in written fiction - the later analysis of the corpus provides a possible reason. The 
Maja Séguin: Corpus based study of verby explain and clarify as an example of assistance in pedagogical settings

second is the gender bias for which no attempt is made to find an answer in this paper.

\subsection{Using the corpus in explaining clarify's patterns}

The first pattern that appears in the 100-line sample of ' $\{$ clarify/V\}' is how 'help' frequently appears to the left. Table 7 lists other verbs within a close distance of clarify in the sample, ${ }^{1}$ and Table $8^{2}$ lists collocates from the full corpus. Although the verb 'be' in its various forms is the most frequent collocation, its use as an auxiliary verb does not make for a special pattern, shown by the fact that 'help' is the strongest collocation based on statistical ranking in the corpus.

Trying to understand what can/cannot be clarified based on this leads to the idea that 'help' could be indicating a lack of confidence that the object will be completely understood after the clarifications. Several other verbs that are likely collocates ('seek', 'try', 'aim', 'attempt') fit that role. It could be that the object being clarified is either complicated or vague in such a way that even after the given clarification it may not be fully understood by the listener. A second pattern that appears, regardless of tense is that clarify is frequently (30 times) followed by the article 'the' immediately to the right hinting to a frequent usage of the verb in an active form with a simple term article, adjective(s), noun - immediately following it which introduces the object under clarification.

Table 7: Clarify: collocated verbs from sample ordered by collocate frequency

\begin{tabular}{|c|c|}
\hline Lemma (verb) & Observed collocate frequency \\
\hline be & 17 \\
\hline help & 11 \\
\hline may & 6 \\
\hline have & 6 \\
\hline can & 5 \\
\hline will & 5 \\
\hline need & 4 \\
\hline must & 3 \\
\hline should & 2 \\
\hline
\end{tabular}

\footnotetext{
${ }^{1}$ Used the saved search results from ' $\{$ clarify/V\} thinned to 100 results; used the collocations tool on this limited set to pull up collocations on POS-tags, range 3 left - 1 left, minimum frequency (collocate, node \& collocate) were set to 2 . The class filter was set to filter for verbs.

2 Used search query ' $\{$ clarify/V\}'; used the collocations tool on this full set to pull up collocations on POS-tags, range 3 left - 1 left, minimum frequency (collocate, node \& collocate) were set to 2 . The class filter was set to filter for verbs.
} 
Maja Séguin: Corpus based study of verby explain and clarify as an example of assistance in pedagogical settings

Table 8: Clarify: collocated verbs from corpus ordered by log-likelihood

\begin{tabular}{|l|c|c|}
\hline Lemma & Observed collocate frequency & Log-likelihood value \\
\hline help & 76 & 452.1587 \\
\hline can & 72 & 167.3514 \\
\hline should & 44 & 132.1665 \\
\hline will & 69 & 128.5352 \\
\hline be & 297 & 117.6842 \\
\hline need & 32 & 108.3004 \\
\hline seek & 17 & 80.7928 \\
\hline try & 23 & 72.1474 \\
\hline may & 31 & 71.9683 \\
\hline design & 10 & 44.106 \\
\hline aim & 8 & 38.3964 \\
\hline attempt & 8 & 37.5633 \\
\hline have & 94 & 35.1077 \\
\hline could & 25 & 34.6621 \\
\hline like & 12 & 29.3362 \\
\hline
\end{tabular}

A count of POS tags (from BNC) immediately following the verb³ (Table 9) confirms this is in fact the most popular form.

Table 9: Clarify: colligates from sample ordered by collocate frequency

\begin{tabular}{|c|c|}
\hline Lemma (verb) & Observed collocate frequency \\
\hline AT0 & 33 \\
\hline DT0 & 12 \\
\hline NN2 & 8 \\
\hline PRP & 7 \\
\hline CJC & 6 \\
\hline DTQ & 5 \\
\hline PUN & 5 \\
\hline DPS & 3 \\
\hline AVQ & 3 \\
\hline CJT & 2 \\
\hline AV0 & 2 \\
\hline NNS1-VVG & 2 \\
\hline
\end{tabular}

General determiners (DT0) fit the simple term pattern being clarified apart from the few cases when it is used alone (ex: "... to clarify this." [C44])

\footnotetext{
${ }^{3}$ Used the saved search results from \{clarify/V\} thinned to 100 results; used the collocations tool on this limited set to pull up collocations on POS-tags range 1 right - 1 right, minimum frequency (collocate, node \& collocate) were set to 2 .
} 
Maja Séguin: Corpus based study of verby explain and clarify as an example of assistance in pedagogical settings

where it refers to preceding clauses with the element to be clarified. This does not break the pattern if we consider punctuation or a conjunction encountered before a noun would indicate the end of the clause.

Likewise, nouns (NN2 and NN1) also fit the simple terms pattern if we consider articles and determiners as optional. Together, these three types of words immediately following the verb match more than half of the lines of the sample (57).

Seeking to identify the topics as simple terms that are typically clarified, Table 10 lists the nouns that repeat themselves in the sample at least twice and already certain meanings could be assumed (shown as grouping).

Table 10: Clarify: collocated nouns from sample ordered by collocate frequency

\begin{tabular}{|c|c|l|}
\hline Lemma (SUBST) & Observed collocate frequency & Grouping \\
\hline issue & 6 & Situation \\
\hline problem & 5 & Situation \\
\hline position & 4 & Situation/mental \\
\hline role & 3 & Purpose \\
\hline thing & 2 & Other \\
\hline nature & 2 & Purpose \\
\hline objective & 2 & Purpose \\
\hline aim & 2 & Purpose \\
\hline
\end{tabular}

Turning to the full corpus with this theory of simple terms being frequent and that the more popular nouns in those terms could potentially be grouped, a search was made for nouns following the verb clarify with optionally POS previously identified in between that apply to the simple terms ${ }^{4}$. This search returned 824 hits representing $~ 57 \%$ of the occurrences of the verb.

As having the noun tag as part of the query precludes the use of the collocations tooling, and lacking control over the greediness modifiers in BNC web ${ }^{5}$ a simplified query ${ }^{6}$ was used resulting in 804 results on which the collocations tool was applied. Again, grouping was attempted for the top collocates what led to 'situation' and 'purpose' fitting to most of the statistically strongest collocations. The results in Table 11 give a first

\footnotetext{
${ }^{4}$ The query used was $\{$ clarify $/ \mathrm{V}\}\left(\text { _ }\{\mathrm{ADV}\}\left|{ }_{-}\{\mathrm{ART}\}\right|{ }_{2}\{\mathrm{ADJ}\}\left|\_\mathrm{DT} 0\right| \_\mathrm{DPS}\right)^{*} \_\{\mathrm{N}\}$

${ }^{5}$ Based on possibilities described in The CQP Query Language Tutorial (Evert: 2009) a query [(lemma="clarify.*") \& (pos="V.*")] [(pos="A.* ")+; set MatchingStrategy longest; was attempted with BNCweb (complex query), however this leads to a parsing error. No error is encountered if set MatchingStrategy is removed. No search modifiers are mentioned in the syntax for simple searches to control greediness.

${ }^{6}$ The query used was $\{$ clarify $/ \mathrm{V}\}\left(\_\{\mathrm{ADV}\} \mid\right.$ _ $_{\text {ART }\}} \mid$ _ $\{\mathrm{ADJ}\}_{\mid}$_DT0 | _DPS $)$
} 
impression as to what topics can be 'clarified'.

Table 11: Clarify: collocated nouns from corpus ordered by log-likelihood

\begin{tabular}{|l|c|c|l|}
\hline $\begin{array}{l}\text { Lemma } \\
\text { (SUBST) }\end{array}$ & $\begin{array}{c}\text { Observed collocate } \\
\text { frequency }\end{array}$ & $\begin{array}{c}\text { Log-likelihood } \\
\text { value }\end{array}$ & Grouping \\
\hline position & 59 & 440.6632 & Situation/mental \\
\hline point & 49 & 290.23 & Purpose \\
\hline issue & 39 & 257.6768 & Situation \\
\hline situation & 26 & 166.8745 & Situation \\
\hline role & 19 & 108.0521 & Purpose \\
\hline meaning & 14 & 97.6994 & Purpose \\
\hline thinking & 11 & 85.5814 & Purpose \\
\hline nature & 15 & 82.6285 & Situation \\
\hline law & 17 & 79.2765 & Other \\
\hline understanding & 11 & 73.3106 & Purpose \\
\hline distinction & 9 & 63.7125 & Situation \\
\hline confusion & 8 & 62.7296 & Situation/mental \\
\hline problem & 17 & 60.6905 & Situation \\
\hline relationship & 12 & 59.98 & Situation \\
\hline policy & 13 & 51.5144 & Situation \\
\hline
\end{tabular}

For verification, the top noun collocates immediately following clarify were also retrieved and presented in Table 12.7 The only new (interesting) noun that appears in that list is 'butter' (as the most frequent and most likely collocate) which fits a secondary definition of making a liquid clear.

\footnotetext{
${ }^{7}$ Query used: \{clarify/V\}; used the collocations tool on the full set of results to pull up collocations on lemma with the range 1 right -1 right, minimum frequency (collocate, node \& collocate) were set to 3. Lemma class was filtered for SUBST.
} 
Maja Séguin: Corpus based study of verby explain and clarify as an example of assistance in pedagogical settings

Table 12: Clarify: collocated nouns in R1 from corpus ordered by loglikelihood

\begin{tabular}{|l|c|c|l|}
\hline Lemma (SUBST) & $\begin{array}{c}\text { Observed collocate } \\
\text { frequency }\end{array}$ & $\begin{array}{c}\text { Log-likelihood } \\
\text { value }\end{array}$ & Grouping \\
\hline butter & 13 & 135.7011 & Other \\
\hline issue & 10 & 48.4678 & Situation \\
\hline responsibility & 4 & 18.4942 & Purpose \\
\hline matter & 5 & 17.8759 & Situation \\
\hline thing & 7 & 15.9343 & Other \\
\hline objective & 3 & 15.1082 & Purpose \\
\hline aim & 3 & 14.932 & Purpose \\
\hline point & 5 & 12.3706 & Purpose \\
\hline problem & 4 & 7.2989 & Situation \\
\hline
\end{tabular}

\subsection{Using the corpus to help in clarifying explain}

In its sample, explain does not show the same trends as clarify. First, no special pattern appears based on verbs preceding explain (Table 138) - the only preceding lexical verb repeating itself is 'try' but appearing only twice. Second, although explain is sometimes followed immediately by 'the', it is less frequent than for clarify (10 times vs 30 times).

Table 13: Explain: collocated verbs from sample ordered by collocate frequency

\begin{tabular}{|c|c|}
\hline Lemma (verb) & Observed collocate frequency \\
\hline be & 24 \\
\hline have & 8 \\
\hline can & 6 \\
\hline could & 3 \\
\hline try & 2 \\
\hline may & 2 \\
\hline
\end{tabular}

A pattern that does come up frequently is 'reported speech' - 23 of the sample's lines contain quoted speech (Appendix 3). Elements from the sample identifying quoted speech are the presence of quotes to the left or right within a near distance, a colon immediately following the verb, a proper name immediately before or after. ${ }^{9}$ A query for such lines returns

\footnotetext{
${ }^{8}$ Used the saved search results from ' $\{$ explain/V' $\}$ thinned to 100 results; used the collocations tool on this limited set to pull up collocations on POS-tags range 3 left - 1 left, minimum frequency (collocate, node \& collocate) were set to 2 . Class filter was set to verb.

${ }^{9}$ Query used: ( $\{$ explain/V\} $\backslash: \mid\{$ explain/V\}_NP0 | _NP0 $\{$ explain/V\} | PNP $\{$ explain/V\} | _PUQ ${ }^{* * *}\left\{\right.$ explain/V\} | \{explain/V\} $\left.{ }^{* * *} \_P U Q\right)$
} 
Maja Séguin: Corpus based study of verby explain and clarify as an example of assistance in pedagogical settings

7935 hits. If explain is used for quoting speech frequently, this can explain the difference in the utilization in novels (fiction and verse) between explain and clarify.

Using a table of colligate (POS items) immediately following the verb shows different patterns than for clarify. Table 14 shows the top 5 colligates for clarify and for explain as comparison.

Table 14: Explain and clarify - top 5 colligates compared

\begin{tabular}{|l|c|c|c|c|}
\hline \multicolumn{1}{|c|}{ Tag } & Rank & $\begin{array}{c}\text { Collocate } \\
\text { frequency }\end{array}$ & Rank & $\begin{array}{c}\text { Collocate } \\
\text { frequency }\end{array}$ \\
\hline PUN & 1 & 22 & 7 & 5 \\
\hline PRP & 2 & 19 & 4 & 7 \\
\hline AVQ & 3 & 11 & 9 & 3 \\
\hline AT0 & 4 & 10 & 1 & 33 \\
\hline CJT & 5 & 9 & 10 & 2 \\
\hline AT0 & 4 & 10 & 1 & 33 \\
\hline DT0 & 7 & 4 & 2 & 12 \\
\hline NN2 & N/A & 0 & 3 & 8 \\
\hline PRP & 2 & 19 & 4 & 7 \\
\hline CJC & 12 & 2 & 5 & 6 \\
\hline
\end{tabular}

Looking at the colligates for explain from the sample, the most frequent one - punctuation - mostly comes from lines with quoted text. The prepositions 'by' and 'to' are often used in sentences with a passive voice while other prepositions (in, within, since, as, on) even if used in a sentence with an active voice, make it such that the object is further off.

The Wh-adverbs (AVQ) - why and how in the sample - and the conjunction 'that' act as the object to be explained, with a fuller and more complex description generally following to the right. 'The' introduces relatively simple objects very close to the verb still on the right.

From the sample, it could be concluded that more complex topics are frequently the object of explain introduced by 'that', 'how' and 'why'.

Using the top colligates (Articles - AT0, Wh-adverbs AVQ, subordinating conjunction that - CJT, prepositions - PRP) immediately following explain ${ }^{10}$ in the sample, combined with the analysis above as to which side of the verb would the object of explain be found, leads to no new major patterns in terms of collocates (tables with the top 15 collocates per POS tags are available in

${ }^{10}$ Query used: \{explain/V\}; used the collocations tool on the full set of results to pull up collocations on POS-tags with the range 1 right - 1 right; minimum frequency (collocate,node \& collocate) were set to 1 . Opened up list of lines matching specific POS tags, and used the collocate tool on those subsets of the results. 
Maja Séguin: Corpus based study of verby explain and clarify as an example of assistance in pedagogical settings

appendix \#4): based on log-likelihood and mutual-information statistical rankings, no terms eclipse or come close to those of 'that', 'how' and 'why' in such conditions.

Finally, the top general collocates sorted by log-likelihood (Table 15) show the same results as above, with the addition of 'what' following the verb used to refer to a more complex clause as the object being described.

Table 15: Explain: general colocations from corpus ordered by log-likelihood

\begin{tabular}{|l|c|c|}
\hline Lemma & Observed collocate frequency & Log-likelihood value \\
\hline why & 1652 & 10181.7484 \\
\hline how & 1041 & 4019.2333 \\
\hline that & 1910 & 2668.2146 \\
\hline the & 6047 & 1428.2652 \\
\hline what & 746 & 1253.0517 \\
\hline term & 330 & 1142.3733 \\
\hline by & 922 & 808.7184 \\
\hline$:$ & 569 & 657.3993 \\
\hline behavior & 113 & 399.636 \\
\hline phenomenon & 72 & 372.3533 \\
\hline t & 917 & 349.8931 \\
\hline everything & 117 & 348.8142 \\
\hline to & 2326 & 335.8554 \\
\hline difference & 117 & 335.2195 \\
\hline he & 1207 & 276.3146 \\
\hline
\end{tabular}

\section{Conclusion}

This paper explored the usage of two synonymous verbs through their usage in sampled texts. This was possible due to the BNCweb tooling. While some features would have been nice to have - such as control over the matching strategy/greediness or position searches combined with grammatical tags, which are available with other tools, these are not considered likely to have impacted the results significantly. This paper does not present an exhaustive list of patterns and identifies certain differences (the distribution between genders) which could require further investigation in future work. Certain possible patterns were identified and demonstrated to be applicable to numerous texts.

Although dictionaries state that the function of the chosen verbs is to make something easier to understand, they have other uses: explain is used frequently to report speech and clarify is used in some rare cases in the sense of making a liquid clear. When they are used in a context of understanding, 
explain is used frequently with complex clauses as object, introduced by key words such as 'why' and 'how', 'that' and 'what'; clarify is used frequently with simple clauses as object ('position', 'point'), but those terms refer to abstract elements such as general situations, purpose or elements which are otherwise mental in nature.

Sinclair's process provided a good foundation for a general analysis discovering patterns, but stopping too soon in looking at sample lines could have missed rarer meanings which were revealed using further searches on and general collocations found within the corpus. Using corpora in the classroom would require advanced research techniques and extensive work on finding possible differences but would provide a potential of teaching preconstructed phrases and explore with learners the words in their context setting.

\section{References}

Ädel, Annelle (2010). Using Corpora to Teach Academic Writing: Challenges for the Direct Approach. Corpus Based Approaches to ELT. London, UK: Continuum.

Andersen, Gisle (2010). How to use corpus linguistics in sociolinguistics. O'Keeffe, Anne, Michael McCarthy, eds. (2010) The Routledge Handbook of Corpus Linguistics. Abingdon: Routledge, 547-562.

Bell, Allan (1991). The Language of News Media. Oxford: Basil Blackwell.

Biber, Douglas, Susan Conrad, Randi Reppen (2000). Corpus Linguistics: Investigating Language Structure and Use. Cambridge: Cambridge University Press.

Biber, Douglas, Edward Finnegan (2014) [1991]. On the exploitation of computerized corpora in variation studies. Aijmer, Karin, Bengt Altenberg, eds. (2014) English Corpus Linguistics. London: Longman, 204-220.

Boulton, Alex, Tom Cobb (2017). Corpus use in language learning: A meta-analysis. Language Learning, 67(2): 348-393

Cobb, Tom, Alex Boulton (2015). Classroom applications of corpus analysis. Biber, Douglas, Randi Reppen, eds. Cambridge Handbook of English Corpus Linguistics. Cambridge: Cambridge University Press, 478-497.

Corino, Elisa, Cristina Onesti (2019). Data-driven learning: a scaffolding methodology for CLIL and LSP teaching and learning. Frontiers in Education 4: 7.

Cruse David Alan (1986). Lexical Semantics. Cambridge: Cambridge University Press.

Divjak, Dagmar (2008). Ways of intending: Delineating and structuring nearsynonyms. Gries, Stefan T., Anatol Stefanowitsch, eds. Corpora in Cognitive Linguistics: Corpus-based Approaches to Syntax and Lexis. Berlin: Mouton de Gruyter, 19-56.

Divjak, Dagmar (2010). Structuring the Lexicon. Berlin, New York: De Gruyter Mouton.

Emons, Rudolf (1997). Corpus linguistics: Some basic problems. Studia Anglica Posnaniensia 32: 61-68.

Evert, Stefan (2009). The CQP Query Language Tutorial. (www) http://cwb.source forge.net/temp/CQPTutorial.pdf (15 June 2017) 
Maja Séguin: Corpus based study of verby explain and clarify as an example of assistance in pedagogical settings

Flowerdew, Lynne (2011). Corpora and Language Education. Basingstoke: Palgrave Macmillan.

Gilquin, Gaëtanelle, Sylviane Granger (2010). How can data-driven learning be used in language teaching. O'Keeffe, Anne, Michael McCarthy, eds. The Routledge Handbook of Corpus Linguistics. Abingdon: Routledge, 359-370.

Glynn, Dylan (2014). Techniques and tools. Corpus methods and statistics for semantics. Glynn, Dylan, Justyna Robinson, eds. Corpus Methods for Semantics. Quantitative studies in polysemy and synonymy. Amsterdam: John Benjamins, 1-6.

Gries, Stefan (2015). Some Current Quantitative Problems in Corpus Linguistics and a Sketch of Some Solutions. Language and Linguistics 16(1): 93-117.

Halliday, Michael A.K. (1966). Lexis as a linguistic level. Bazell, Charles E., John C. Catford, Michael A. K. Halliday, Robert H. Robins, eds. In Memory of J. R. Firth. London: Longman, 148-162.

Hunston, Susan, Gill Francis (2000). Pattern Grammar: A Corpus-Driven Approach to the Lexical Grammar of English. Amsterdam: John Benjamins Publishing Company.

Hunston, Susan (2002). Corpora in Applied Linguistics. Cambridge: Cambridge University Press.

Inkpen, Diana, Graeme Hirst (2006). Building and Using a Lexical Knowledge Base of Near-Synonym Differences. Computational Linguistics 32: 223-262

McEnery, Tony, Andrew Hardie (2012). Corpus Linguistics: Method, Theory and Practice. Cambridge: Cambridge University Press.

McEnery, Tony, Richard Xiao, Yukio Tono (2006). Corpus-Based Language Studies: An Advanced Resource Book. London, New York: Routledge.

Michel, Jean-Baptiste, Yuan Kui Shen, Aviva P. Aiden, Adrian Veres, Matthew K. Gray, The Google Books Team, Joseph P. Pickett, et al. (2011) Quantitative analysis of culture using millions of digitized books. Science 331(6014): 176182.

O'Keeffe, Anne, Michael McCarthy (eds.) (2010). The Routledge Handbook of Corpus Linguistics. Abingdon: Routledge.

Rayson, Paul, Dawn Elizabeth Archer, Alistair Baron, Jonathan Culpeper, Nicholas Smith (2007). Tagging the bard: Evaluating the accuracy of a modern POS Tagger on Early Modern English corpora. Corpus Linguistics Conference 2007 (CL2007), 27 July 2007 - 30 July 2007, University of Birmingham, UK.

Sinclair, John (1991). Corpus, Concordance, Collocation. Oxford: Oxford University Press.

Sinclair, John (2003). Reading Concordances: An Introduction. London: Pearson Education.

Sinclair, John (2004). Trust the Text: Language, Corpus and Discourse. London: Routledge.

Sinclair, John (2005a). Corpus and text - Basic principles. Wynne, Martin, ed. Developing Linguistic Corpora: A guide to Good Practice. Oxford: Oxbow Books. 1-16. http:/ / ota.ox.ac.uk/documents/creating/dlc/chapter1.htm (17 March 2017)

Sinclair, John (2005b). Appendix: How to build a corpus. Wynne, Martin, ed. Developing Linguistic Corpora: A guide to Good Practice. Oxford: Oxbow Books, 79-83. (10 April 2017) http://ota.ox.ac.uk/documents/creating/dlc/appendix.htm

Stubbs, Michael (1995) Collocations and semantic profiles: On the cause of the trouble with quantitative studies. Functions of Language 2(1): 23-55. https:/ /www. 
Maja Séguin: Corpus based study of verby explain and clarify as an example of assistance in pedagogical settings

uni-trier.de/fileadmin/fb2/ANG/Linguistik/Stubbs/stubbs-1995-causetrouble.pdf (4 April 2017)

Stubbs, Michael (2001). Texts, corpora, and problems of interpretation: a response to Widdowson. Applied Linguistics 22(2): 149-172

Stubbs, Michael (2009). The Search for units of meaning: Sinclair on empirical semantics. Applied Linguistics 30(1): 115-137.

Taylor, John R. (2003). Near synonyms as co-extensive categories: 'high' and 'tall' revisited. Language Sciences 25(3): 263-284.

The British National Corpus (3 ${ }^{\text {rd }}$ version, BNC XML Edition) (2007). Distributed by Oxford University Computing Services on behalf of the BNC Consortium (www) http://www.natcorp.ox.ac.uk/ (April-July 2017)

Widdowson, Henry G. (2000). The limitations of linguistics applied. Applied Linguistics 21(1): 3-25.

\section{Author's address:}

Cvjetkova 32

HR-31000 Osijek, Hrvatska

e-mail: Maja.Seguin@evtos.hr

Received: February 18, 2020

Accepted for publication: July 1, 2020 


\section{Appendix 1: 100-line sample for ' $\{$ clarify/V\}'}

\section{Table 16 - clarify, 100 random lines from corpus}

\begin{tabular}{|c|c|c|c|c|}
\hline 1 & $\begin{array}{l}\text { A0J } \\
1900\end{array}$ & $\begin{array}{r}\text { Occupational Therapist for the } \\
\text { work. The Flow Chart may } \\
\text { help to }\end{array}$ & clarify & $\begin{array}{l}\text { the procedure.' Making } \\
\text { adaptations to your home may } \\
\text { seem a }\end{array}$ \\
\hline 2 & $\begin{array}{l}\text { A10 } \\
1317\end{array}$ & $\begin{array}{r}\text { Concern believes that there is } \\
\text { an urgent need for the } \\
\text { Government to }\end{array}$ & clarify & $\begin{array}{l}\text { the role of the health service in } \\
\text { providing community care. } \\
\text { Community }\end{array}$ \\
\hline 3 & $\begin{array}{l}\text { AAY } \\
23\end{array}$ & $\begin{array}{l}\text { negotiate to obtain the best } \\
\text { price. Their purchasing } \\
\text { position will be }\end{array}$ & cla & $\begin{array}{l}\text { and the solicitors notified. } \\
\text { Naturally the final decision is } \\
\text { yours but }\end{array}$ \\
\hline 4 & $\begin{array}{l}\text { AJD } \\
534\end{array}$ & $\begin{array}{l}\text { his audience. 'So I was } \\
\text { delighted when last night he }\end{array}$ & clarified & $\begin{array}{l}\text { the issue for the nation. As } \\
\text { vicars say, I would }\end{array}$ \\
\hline 5 & $\begin{array}{l}\text { AMG } \\
232\end{array}$ & $\begin{array}{l}\text { to a large extent an exercise in } \\
\text { extrapolation. I attempt to }\end{array}$ & clarify & $\begin{array}{l}\text { the roots of human cognition } \\
\text { in their primordial states. An } \\
\text { ethology }\end{array}$ \\
\hline 6 & $\begin{array}{l}\text { AMT } \\
1193\end{array}$ & $\begin{array}{r}\text { what we mean by } \\
\text { 'transcendence', so the first } \\
\text { principle }\end{array}$ & es & $\begin{array}{l}\text { what we mean by } \\
\text { 'immanence'. God is not to }\end{array}$ \\
\hline 7 & AP1 & $\begin{array}{l}\text { invoice for the tape, but will } \\
\text { cancel it once we have }\end{array}$ & clarified & $\begin{array}{l}\text { the } \\
\text { rece }\end{array}$ \\
\hline 8 & $\begin{array}{l}\mathrm{B} 0 \mathrm{H} \\
1137\end{array}$ & $\begin{array}{r}\text { decided without troubling the } \\
\text { whole Cabinet; and major } \\
\text { issues to be }\end{array}$ & ed & $\begin{array}{l}\text { in order to save the time of the } \\
\text { Cabinet. The method }\end{array}$ \\
\hline 9 & $\begin{array}{l}\text { B2D } \\
746\end{array}$ & $\begin{array}{l}1906 \text { (as amended). Perhaps } \\
\text { there is an argument for }\end{array}$ & cla & $\begin{array}{l}\text { and formalising this co- } \\
\text { operation. NON-LEGAL } \\
\text { CONTROLS The Ombudsmen } \\
\text { An avenue open }\end{array}$ \\
\hline 10 & $\begin{array}{l}\text { B2F } \\
1000\end{array}$ & $\begin{array}{l}\text { routine to follow when setting } \\
\text { an objective for an interaction: }\end{array}$ & clarify & $\begin{array}{l}\text { the overall aim (ie the longer } \\
\text { term end result). }\end{array}$ \\
\hline 11 & $\begin{array}{l}\text { B2M } \\
986\end{array}$ & $\begin{array}{l}\text { were considered necessary to } \\
\text { progress the study, ie one } \\
\text { concerned with }\end{array}$ & & $\begin{array}{l}\text { roles and information needs, } \\
\text { and the second exploring and } \\
\text { quantifying the }\end{array}$ \\
\hline 12 & $\begin{array}{l}\text { B7J } \\
1925\end{array}$ & $\begin{array}{r}\text {, so that the causal influence of } \\
\text { lead on IQ is not }\end{array}$ & clarified & $\begin{array}{l}\text { in the experiment. However, } \\
\text { in principle this would seem } \\
\text { to }\end{array}$ \\
\hline 13 & $\begin{array}{l}\text { BLY } \\
1441\end{array}$ & $\begin{array}{r}\text { on examination and selection } \\
\text { in African schools has done so } \\
\text { much to }\end{array}$ & clarify & $\begin{array}{l}\text { problems and suggest } \\
\text { solutions: 'If the Certificate of } \\
\text { Primary Education }\end{array}$ \\
\hline 14 & $\begin{array}{l}\text { BME } \\
301\end{array}$ & $\begin{array}{r}\text { and/or manager is a } \\
\text { prerequisite for good } \\
\text { communication. Instructions } \\
\text { must be }\end{array}$ & cla & $\begin{array}{l}\text { and the instructor should } \\
\text { probe when appropriate to } \\
\text { ensure that his requirements }\end{array}$ \\
\hline
\end{tabular}


$15 \mathrm{BMH}$ together still underpin modern 361 legislation on obscenity. Lord clarifying the scope of the Act, stated Campbell, in

16 CAJ which was last modified by the 747 Court of Cassation in 1985 to

clarify crime in question must be accept late partnership

17 CBT 3146 continuation elections in certain situations, which were recently Ł6.85, from HMSO.

18 CBW 3339

WESTMINSTER UPDATE Late filing of accounts dates

19 CBX 225 . In July, the Urgent Issues Task Force released a clarifying consensus of matters under discussion, 1401 and of asking questions which helped to

CGD Networks Project (Sinclair et al 1345 , 1984) helped to

CHT 392

in breach of proper professional conduct. This exercise should help to

23 CJG

CJG additional explanatory services 365 of processes may be needed to 's reforming zeal are as yet 24 unknown. The White Paper

CMM Before looking at the bloom 69 shapes and forms, we need to

CN6

system, with its inconsistencies 832 and confusion, conciliation services to help

CR5 long established customs. A 360 DoH spokesman said the new guidance will

28 CRW the phrase is to be infused with 304 greater meaning, and to

CS2 action is right, if the latter it is 22 planning and decisions. I

clarify could not help feeling that if we

how informal_ADJ care

clarify networks function. It looked at formal and informal the kind of theoretical and

clarify practical knowledge you need to update and work in mathematics and the

clarify sciences. For those pupils who possess

clarify many of these issues and will give a good idea as to a few terms which are not as clarify simple or straightforward as might arrangements in the best interests of children and encourage joint parental responsibilities where inspectors can play a clarify legitimate role. He admitted drawing the whether what is meant is the best interests of all children in this, Bentham lists seven soclarify called dimensions of pleasure and pain: 
30 CSC 214
Software Inc, a noticeably popular fashion in start-ups this season.

31 EAJ book. Oakeshott's objective in 43 Experience and its Modes is to

32 EEN . But before looking in more we must never be

EW6 . It is not possible in a modest $401 \quad$ book like this to 1506

automatically shares your 35

$\begin{array}{lll}36 & \text { F9T } & \text { at some of the ideas associated } \\ 2227 & \text { with each approach may help }\end{array}$

37 FA3 explored in Chapter 3. The 743 model also goes some way to

$\begin{array}{ll}\text { FA9 Understandable though this } \\ 34 & \text { might be, it still leaves }\end{array}$ FA9 to undermine the
37 revolutionary claims. Instead, it is hoped to clarify , however, is positioning itself against the others as the most

clarify method is to distinguish philosophy, the focus of our argument.

clarify Robert Padgug has recently written that . She had returned to El

clarified Salvador in January to collect evidence everything. For the moment

clarify just note that electron spin provides a your position, make your clarify assumptions explicit and your meaning as clear further the differences clarify between them (see Table 8.1). The the problem of the clarify 'humanities'. It suggests that of some central issues relating to

clarify the important, but difficult, concept by investigating the son of

40 FA9 particular sense of the term 43 will become clarified socially shared beliefs which can be distinguished the distinction between

41 FAF electorate. At the outset, 1171 however, it is important to

FAM i.e. national, local and school, 214 and in an attempt to

FRN 339 ) remarks that these 1985 particularly successful in often part of the actual FS6 disorder. Some examples

clarify

the distinction between marginal and average rates of tax. In public them the following

clarify paragraphs examine each in turn. According to the the issues, and vertical Guidelines have not been clarifying restraints remain an unsatisfactory area of US might help to this. If a child is born with some degree of mental 
Maja Séguin: Corpus based study of verby explain and clarify as an example of assistance in pedagogical settings

\begin{tabular}{|c|c|c|c|}
\hline 45 & $\begin{array}{l}\text { FSY } \\
120\end{array}$ & $\begin{array}{l}\text { for } \AA \text {-myosin heavy chain in } \\
\text { some families with the clarified } \\
\text { condition has both }\end{array}$ & $\begin{array}{l}\text { the nature of the genetic defect } \\
\text { and simultaneously raised the } \\
\text { prospect of }\end{array}$ \\
\hline 46 & $\begin{array}{l}\text { FTV } \\
368\end{array}$ & $\begin{array}{l}\text { It is claimed that the meaning } \\
\text { of existential assertions can be clarified } \\
\text { fully }\end{array}$ & $\begin{array}{l}\text { only by clarifying the mode of } \\
\text { being of the one who makes }\end{array}$ \\
\hline 47 & $\begin{array}{l}\text { FU3 } \\
862\end{array}$ & $\begin{array}{l}\text { between the different types of } \\
\text { history books. E. CHECKLIST clarify } \\
2 .\end{array}$ & $\begin{array}{l}\text { your understanding of the } \\
\text { main differences between } \\
\text { narrative, description and } \\
\text { analysis }\end{array}$ \\
\hline 48 & $\begin{array}{l}\text { G0N } \\
1284\end{array}$ & $\begin{array}{l}10 \text { Derek's previous experience } \\
\text { of dealing with the police clarifying } \\
\text { amounted to }\end{array}$ & $\begin{array}{l}\text { some technical points for the } \\
\text { Fraud Squad when a client of } \\
\text { Fithyan }\end{array}$ \\
\hline 49 & $\begin{array}{l}\text { G1F } \\
1313\end{array}$ & $\begin{array}{c}\text { telling teachers how to teach? } \\
\text { Or should policy concentrate clarifying } \\
\text { more on }\end{array}$ & $\begin{array}{l}\text { the goals and outcomes of } \\
\text { learning, and on providing } \\
\text { the kind }\end{array}$ \\
\hline 50 & $\begin{array}{l}\mathrm{G} 1 \mathrm{H} \\
388\end{array}$ & $\begin{array}{r}\text { Before discussing possible } \\
\text { explanations of football clarify } \\
\text { hooliganism, it is necessary to }\end{array}$ & $\begin{array}{l}\text { the different forms of } \\
\text { behaviour incorporated within } \\
\text { this term, where these }\end{array}$ \\
\hline 51 & $\begin{array}{l}\mathrm{G} 3 \mathrm{H} \\
1502\end{array}$ & $\begin{array}{l}\text { put to the test. The Minister clarify } \\
\text { now has an opportunity to }\end{array}$ & $\begin{array}{l}\text { that position. I assume that he } \\
\text { has the information in front }\end{array}$ \\
\hline 52 & $\begin{array}{l}\text { GUJ } \\
929\end{array}$ & $\begin{array}{l}\text { But most of these can be } \\
\text { regarded as experimental clarify } \\
\text { works designed to }\end{array}$ & $\begin{array}{l}\text { the problems that Picasso was } \\
\text { facing in his painting. Picasso, }\end{array}$ \\
\hline 53 & $\begin{array}{l}\text { GVU } \\
2118\end{array}$ & $\begin{array}{r}\text {, so much so that laws have to clarify } \\
\text { be passed to }\end{array}$ & $\begin{array}{l}\text { ' the original intention. } \\
\text { Interpretations of statute are } \\
\text { not unfamiliar to }\end{array}$ \\
\hline 54 & $\begin{array}{l}\text { GXG } \\
237\end{array}$ & $\begin{array}{c}\text { Environmental Bureau, of } \\
\text { which we are members, and clarifying } \\
\text { aimed at }\end{array}$ & $\begin{array}{l}\text { our objectives for European } \\
\text { Community action (a } \\
\text { Directive?) on }\end{array}$ \\
\hline 55 & $\begin{array}{l}\text { GXG } \\
1165\end{array}$ & $\begin{array}{r}\text { very useful if we could meet } \\
\text { you to explore shared interests clarify } \\
\text { and }\end{array}$ & $\begin{array}{l}\text { how best we can work } \\
\text { together on this issue. In the }\end{array}$ \\
\hline 56 & $\begin{array}{l}\text { GXJ } \\
1491\end{array}$ & $\begin{array}{c}\text { on the proposed arrangements } \\
\text { is available for comment. Key clarifying } \\
\text { Task } 4\end{array}$ & $\begin{array}{l}\text { the roles of general } \\
\text { practitioners and primary } \\
\text { health care teams Lead Role }\end{array}$ \\
\hline 57 & $\begin{array}{l}\text { HOY } \\
1022\end{array}$ & $\begin{array}{r}\text { authority" during lesson. } 10 \\
\text { Use facial expressions and clarify } \\
\text { gestures to }\end{array}$ & $\begin{array}{l}\text { meaning. Present new words } \\
\text { in context. } 11 \text { Vary voice - }\end{array}$ \\
\hline 58 & $\begin{array}{l}\text { H7Y } \\
1375\end{array}$ & $\begin{array}{l}\text { resemble the examples } \\
\text { alongside the Irchester road, clarified } \\
\text { but here excavations have }\end{array}$ & $\begin{array}{l}\text { aspects of their chronology } \\
\text { and function. Work at the } \\
\text { north end }\end{array}$ \\
\hline 59 & $\begin{array}{l}\text { H83 } \\
1501\end{array}$ & $\begin{array}{c}\text { sake. Lack of sufficient } \\
\text { proportion, clarity or similarity clarifying } \\
\text { means that }\end{array}$ & $\begin{array}{l}\text { and distinguishing the data is } \\
\text { so fraught with excessive } \\
\text { difficulty that interest }\end{array}$ \\
\hline
\end{tabular}


Maja Séguin: Corpus based study of verby explain and clarify as an example of assistance in pedagogical settings

\begin{tabular}{|c|c|c|c|c|}
\hline 60 & $\begin{array}{l}\mathrm{H} 88 \\
1375\end{array}$ & $\begin{array}{r}\text { assess or evaluate } \\
\text { mathematical attainment or } \\
\text { progress in learning, we must }\end{array}$ & clarify & $\begin{array}{l}\text { what we mean by 'doing } \\
\text { mathematics'. Does it, }\end{array}$ \\
\hline 61 & $\begin{array}{l}\text { HAC } \\
5896\end{array}$ & $\begin{array}{l}\text { Practical PC and I feel certain } \\
\text { points about Windows } \\
\text { Multimedia capabilities need }\end{array}$ & c & $\begin{array}{l}\text { Although the soundblaster } \\
\text { and Adlib cards are } \\
\text { mentioned in the same }\end{array}$ \\
\hline 62 & $\begin{array}{l}\text { HB3 } \\
1482\end{array}$ & $\begin{array}{l}\text { on the way claims are handled. } \\
\text { The following section attempts } \\
\text { to }\end{array}$ & clarify & $\begin{array}{l}\text { some of the more common } \\
\text { areas where } \\
\text { misunderstanding can occur. } \\
\text { GENERAL }\end{array}$ \\
\hline 63 & $\begin{array}{l}\mathrm{HC} 4 \\
82\end{array}$ & $\begin{array}{r}\text { limited tolerances which are } \\
\text { difficult to apply in practice; } \\
\text { and to }\end{array}$ & clarify & $\begin{array}{l}\text { which types of fish are } \\
\text { covered by controls. A more } \\
\text { thorough }\end{array}$ \\
\hline 64 & $\begin{array}{l}\text { HGY } \\
3016\end{array}$ & $\begin{array}{l}\text { it nice that little Ellie was here } \\
\text { just in time to help }\end{array}$ & clarify & $\begin{array}{l}\text { 'There's nothing to } \\
\text { There was }\end{array}$ \\
\hline 65 & $\begin{array}{l}\text { HHV } \\
18227\end{array}$ & $\begin{array}{l}\text { which will come before the } \\
\text { House on Friday, but did not }\end{array}$ & clarify & $\begin{array}{l}\text { whether he is in favour of a } \\
\text { ban on fox hunting. }\end{array}$ \\
\hline 66 & $\begin{array}{l}\text { HHW } \\
13153\end{array}$ & $\begin{array}{l}\text { policy framework and the } \\
\text { arrangements that would } \\
\text { apply to them. We }\end{array}$ & & $\begin{array}{l}\text { a number of points before the } \\
\text { legislation was introduced. } \\
\text { The Bill }\end{array}$ \\
\hline 67 & $\begin{array}{l}\mathrm{HJ} 2 \\
3443\end{array}$ & $\begin{array}{r}\text {; the latter, by analysing } \\
\text { Chicken and Prisoners' } \\
\text { Dilemma, }\end{array}$ & & $\begin{array}{l}\text { the problem of voluntary co- } \\
\text { operation to achieve valued } \\
\text { goals. In showing }\end{array}$ \\
\hline 68 & $\begin{array}{l}\text { HJ2 } \\
4513\end{array}$ & $\begin{array}{l}\text { The aim of this programme is } \\
\text { to investigate, analyse and }\end{array}$ & clarify & $\begin{array}{l}\text { the various linkages between } \\
\text { government and industry that } \\
\text { exists both in this }\end{array}$ \\
\hline 69 & $\begin{array}{l}\text { HKP } \\
2944\end{array}$ & $\begin{array}{r}\text { in tariff bindings (ie } \\
\text { undertakings not to increase } \\
\text { tariffs) by }\end{array}$ & clar & $\begin{array}{l}\text { nd charges, } \\
\text { inary }\end{array}$ \\
\hline 70 & $\begin{array}{l}\text { HL3 } \\
1262\end{array}$ & $\begin{array}{r}\text { Salvadorean government and } \\
\text { the US administration itself, in } \\
\text { its efforts to }\end{array}$ & clarify & $\begin{array}{l}\text { nts. Cabinet change } \\
\text { bantamaría left his post } \\
\text { ce }\end{array}$ \\
\hline 71 & $\begin{array}{l}\text { HNW } \\
2042\end{array}$ & $\begin{array}{l}\text { Primary teachers seem to have } \\
\text { found the review of most value } \\
\text { in }\end{array}$ & & $\begin{array}{l}\text { aims and objectives (least, } \\
\text { secondary), improving } \\
\text { resources ( }\end{array}$ \\
\hline 72 & $\begin{array}{l}\mathrm{HPF} \\
413\end{array}$ & $\begin{array}{l}\text { in turn below, but the objective } \\
\text { of risk management should be }\end{array}$ & clarified & $\begin{array}{l}\text { first: it should contribute to } \\
\text { the business objectives and not } \\
\text { be }\end{array}$ \\
\hline 73 & $\begin{array}{l}\text { HPU } \\
165\end{array}$ & $\begin{array}{l}\text { discussion of some of the more } \\
\text { directly relevant philosophical } \\
\text { issues may help }\end{array}$ & clarify & $\begin{array}{l}\text { matters. It is possible to } \\
\text { distinguish, albeit rather } \\
\text { grossly, }\end{array}$ \\
\hline 74 & $\begin{array}{l}\text { HRM } \\
1970\end{array}$ & $\begin{array}{l}\text { the state bureaucracies which } \\
\text { Weberians emphasise. The } \\
\text { point can now be }\end{array}$ & clar & $\begin{array}{l}\text { by turning to another } \\
\text { illustration, one based on a } \\
\text { contemporary debate }\end{array}$ \\
\hline 75 & $\begin{array}{l}\text { HTV } \\
1051\end{array}$ & $\begin{array}{r}\text { once again, the methodology } \\
\text { of state-centrism serves to blur } \\
\text { rather than }\end{array}$ & & $\begin{array}{l}\text { the issues. The national origin } \\
\text { of the agents of media control }\end{array}$ \\
\hline
\end{tabular}




\begin{tabular}{|c|c|c|c|c|}
\hline 76 & $\begin{array}{l}\text { IU2 } \\
686\end{array}$ & $\begin{array}{r}\text { effectively extracted from the } \\
\text { cells. Further work is in } \\
\text { progress to }\end{array}$ & clarify & $\begin{array}{l}\text { this problem. Our results with } \\
\text { western blotting contrast with } \\
\text { those of }\end{array}$ \\
\hline 77 & $\begin{array}{l}\text { HU2 } \\
2879\end{array}$ & $\begin{array}{r}\text { with that in patients with } \\
\text { established colorectal cancer, } \\
\text { may help to }\end{array}$ & & $\begin{array}{l}\text { this issue. A prolonged colonic } \\
\text { transit time may be expected } \\
\text { to }\end{array}$ \\
\hline 78 & $\begin{array}{l}\text { HU4 } \\
4203\end{array}$ & $\begin{array}{r}\text { The situation with respect to } \\
\text { pressure changes and pain } \\
\text { may be }\end{array}$ & cla & $\begin{array}{l}\text { by prolonged ambulatory } \\
\text { measurements of colonic } \\
\text { pressure activity, which allow } \\
\text { the }\end{array}$ \\
\hline 79 & $\begin{array}{l}\text { HXT } \\
1508\end{array}$ & $\begin{array}{l}\text { their populations. The purpose } \\
\text { of this chapter is to try and }\end{array}$ & clarify & $\begin{array}{l}\text { these issues by asking: (a) } \\
\text { what is quality in }\end{array}$ \\
\hline 80 & $\begin{array}{l}\mathrm{HXV} \\
2372\end{array}$ & $\begin{array}{l}\text { aircraft whilst in flight. The } \\
\text { position of aircraft has also } \\
\text { been }\end{array}$ & & $\begin{array}{l}\text { law. The } \\
\text { took an aerial } \\
\text { of the }\end{array}$ \\
\hline 81 & $\begin{array}{l}\text { HY6 } \\
62\end{array}$ & $\begin{array}{r}\text { creative literature is the } \\
\text { recognition of particular } \\
\text { aspects of experience shaped } \\
\text { and }\end{array}$ & & $\begin{array}{l}\text {, these authors are trying to } \\
\text { share their understanding of } \\
\text { the means }\end{array}$ \\
\hline 82 & $\begin{array}{l}Y 6 \\
0\end{array}$ & $\begin{array}{l}\text { The end of the first half of The } \\
\text { Form is concerned with }\end{array}$ & & $\begin{array}{l}\text { the o } \\
\text { layin }\end{array}$ \\
\hline 83 & $\begin{array}{l}\text { HY6 } \\
1152\end{array}$ & $\begin{array}{l}\text { of the book, ho } \\
\text { occupied with th }\end{array}$ & clarify & $\begin{array}{l}\text { ch the } \\
\text { likeness of }\end{array}$ \\
\hline 84 & $\begin{array}{l}\text { HYB } \\
1366\end{array}$ & & & wl \\
\hline 85 & $\begin{array}{l}\mathrm{J} 2 \mathrm{~K} \\
23\end{array}$ & $\begin{array}{r}\text { is } \\
\text { comr } \\
\text { illu }\end{array}$ & clarify & $\begin{array}{l}\text { the concept: it distinguishes } \\
\text { between two kinds of "boos" }\end{array}$ \\
\hline 86 & $\begin{array}{l}\text { J44 } \\
135 \\
\text { Audi }\end{array}$ & $\begin{array}{r}\mathrm{o} \text {, that was, that wa } \\
\text { reven }\end{array}$ & fy & $\begin{array}{l}\text { that one? I think there's a } \\
\text { Right, }\end{array}$ \\
\hline 87 & $\begin{array}{l}\mathrm{J} 6 \mathrm{Y} \\
859\end{array}$ & $\begin{array}{r}\text { avoid cou } \\
\text { th } \\
\text { discreti }\end{array}$ & & Ltd in \\
\hline 88 & $\begin{array}{l}\text { J73 } \\
197\end{array}$ & new rules to pre & fy & $\begin{array}{l}\text { would } \\
\text { fficulty in }\end{array}$ \\
\hline 89 & $\begin{array}{l}\text { J9T } \\
1037\end{array}$ & $\begin{array}{r}\text { [gap:name] raised last } \\
\text { Thursday of Friday and which } \\
\text { I thought I'd }\end{array}$ & clar & $\begin{array}{l}\text { Leeds position on. We we } \\
\text { draw a clear distinction } \\
\text { between provision }\end{array}$ \\
\hline 90 & $\begin{array}{l}\text { JAC } \\
291 \\
\text { Audi }\end{array}$ & $\begin{array}{l}\text { many days. We were talking } \\
\text { about the new settlement. To }\end{array}$ & clarify & $\begin{array}{l}\text { that we established yesterday } \\
\text { that the new settlement will } \\
\text { not necessarily be }\end{array}$ \\
\hline 91 & $\begin{array}{l}\text { JAD } \\
1161\end{array}$ & $\begin{array}{r}\text { employn } \\
\text { Harrogate, er } \\
\text { disc }\end{array}$ & & $\begin{array}{l}\text { a lot of the the sort of } \\
\text { outstanding issues that that er }\end{array}$ \\
\hline
\end{tabular}


Maja Séguin: Corpus based study of verby explain and clarify as an example of assistance in pedagogical settings

\begin{tabular}{|c|c|c|c|c|}
\hline 92 & $\begin{array}{l}\text { JK0 } \\
381 \\
\text { Audio }\end{array}$ & $\begin{array}{r}\text { previous years accounts, yeah } \\
\text { yes it is can we just erm }\end{array}$ & clarify & $\begin{array}{l}\text { that Mr [gap:name] , of course } \\
\text { it's dealing with the previous }\end{array}$ \\
\hline 93 & $\begin{array}{l}\text { JNN } \\
146 \\
\text { Audio }\end{array}$ & $\begin{array}{l}\text { remarks, it's hardly a question } \\
\text { but perhaps you could just }\end{array}$ & clarify & $\begin{array}{l}\text { Yes. my er thinking on on the } \\
\text { [pause] on what you said }\end{array}$ \\
\hline 94 & $\begin{array}{l}\text { JSF } \\
308\end{array}$ & $\begin{array}{l}\text { object was the same as Sir } \\
\text { Thomas Bingham's, namely to }\end{array}$ & clarify & $\begin{array}{l}\text { and strengthen the position of } \\
\text { the auditor, not to change it }\end{array}$ \\
\hline 95 & $\begin{array}{l}\text { JSF } \\
325\end{array}$ & $\begin{array}{l}\text { madam speaker, er Madam } \\
\text { Deputy Speaker, if I seek to }\end{array}$ & clarify & $\begin{array}{l}\text { er when an individual auditor } \\
\text { is operating in his capacity as } \\
\text { such }\end{array}$ \\
\hline 96 & $\begin{array}{l}\text { JSG } \\
335\end{array}$ & $\begin{array}{l}\text {, what was needed was some } \\
\text { amendment to the banking act } \\
\text { to }\end{array}$ & clarify & $\begin{array}{l}\text { that and that is precisely what } \\
\text { [pause] er this order actually } \\
\text { does and }\end{array}$ \\
\hline 97 & $\begin{array}{l}\text { JY7 } \\
1847\end{array}$ & $\begin{array}{r}\text { name.' It was, she knew, the } \\
\text { moment to }\end{array}$ & clarify & $\begin{array}{l}\text { things, to explain that Paolo } \\
\text { was a company, not a }\end{array}$ \\
\hline 98 & $\begin{array}{l}\mathrm{K} 2 \mathrm{~F} \\
593\end{array}$ & $\begin{array}{r}\text { 'Meetings of all the Palestinian } \\
\text { institutions are starting in } \\
\text { order to }\end{array}$ & clarify & $\begin{array}{l}\text { and decide the prospects for } \\
\text { the political action in the } \\
\text { future, }\end{array}$ \\
\hline 99 & $\begin{array}{l}\text { KM6 } \\
23\end{array}$ & $\begin{array}{l}\text { just sort of clarify this before } \\
\text { going on. Can I just }\end{array}$ & clarify & $\begin{array}{l}\text {, what, what you're saying is } \\
\text { that in a sense [pause] }\end{array}$ \\
\hline 100 & $\begin{array}{l}\text { KRL } \\
521\end{array}$ & $\begin{array}{l}\text { ? Well I think some of the big } \\
\text { problems [pause] if we can }\end{array}$ & clarify & $\begin{array}{l}\text { mechanical breakdown } \\
\text { insurance. Now it is actually } \\
\text { mechanical breakdown } \\
\text { insurance. }\end{array}$ \\
\hline
\end{tabular}




\section{Appendix 2: 100-line sample for ' $\{$ explain/ $\mathrm{V}\}$ '}

Table 17 - explain, 100 random lines from corpus

\begin{tabular}{|c|c|c|c|c|}
\hline 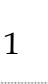 & $\begin{array}{l}\mathrm{A} 00 \\
404\end{array}$ & $\begin{array}{r}\text { get home and has no money } \\
\text { for transport. I try to }\end{array}$ & explain & she will not be staying \\
\hline 2 & $\begin{array}{l}\text { A69 } \\
605\end{array}$ & $\begin{array}{r}\text { avoided. Helmut Schoeck, the } \\
\text { professor of sociology at } \\
\text { Mainz, }\end{array}$ & exp & $\begin{array}{l}\text { the reasons why in a } \\
\text { comprehensive analysis which } \\
\text { restores the phenomenon of }\end{array}$ \\
\hline 3 & $\begin{array}{l}\text { ACK } \\
1545\end{array}$ & $\begin{array}{r}\text { well. 'I'm used to Nigel now, } \\
\text { Elinor }\end{array}$ & $d$ & $\begin{array}{l}\text { to me, 'but it's nice to have a } \\
\text { change }\end{array}$ \\
\hline 4 & $\begin{array}{l}\text { AD2 } \\
988\end{array}$ & $\begin{array}{r}\text { is a large uncommitted } \\
\text { population, this is probably } \\
\text { not something which }\end{array}$ & $\mathrm{ex}$ & $\begin{array}{l}\text { why more people do not join } \\
\text { the Free Church. A second }\end{array}$ \\
\hline 5 & $\begin{array}{l}\text { ADR } \\
1482\end{array}$ & $\begin{array}{r}\text { sex symbol was the Sydney } \\
\text { fashion guru. Nicole } \\
\text { Bonython. She }\end{array}$ & & $\begin{array}{l}\text { :'I wa } \\
\text { minut }\end{array}$ \\
\hline 6 & $\begin{array}{l}\text { AEA } \\
1221\end{array}$ & $\begin{array}{r}\text { dore.' 'I don't feel that you're } \\
\text { really }\end{array}$ & & you \\
\hline 7 & $\begin{array}{l}\text { AM4 } \\
181\end{array}$ & $\begin{array}{l}\text { a fear of stomach cancer. The } \\
\text { first factor, the newspaper }\end{array}$ & & 1972 \\
\hline 8 & $\begin{array}{l}\text { AM6 } \\
481\end{array}$ & $\begin{array}{l}\text { have in common is the } \\
\text { requirement of 'aesthetic } \\
\text { intention', }\end{array}$ & ex & $\begin{array}{l}\text { ght } \\
\text { ghether, }\end{array}$ \\
\hline 9 & $\begin{array}{l}\text { ASF } \\
1030\end{array}$ & $\begin{array}{l}\text { either born or entrustec } \\
\text { his divine mission or die }\end{array}$ & e & $\begin{array}{l}\text { by al } \\
\text { in hi }\end{array}$ \\
\hline 10 & $\begin{array}{l}\text { B08 } \\
1870\end{array}$ & $\begin{array}{r}\text { prepared by the com } \\
\text { initialling a few } \\
\text { pape }\end{array}$ & & $\begin{array}{l}\text { aployers } \\
\text { arting }\end{array}$ \\
\hline 11 & $\begin{array}{l}\text { B20 } \\
1554\end{array}$ & $\begin{array}{r}\text { everything. Now would you } \\
\text { rather answer my questions, } \\
\text { or try }\end{array}$ & & $\begin{array}{l}\text { yourself } \\
\text { headqua } \\
\text { her }\end{array}$ \\
\hline 12 & $\begin{array}{l}\text { B25 } \\
200\end{array}$ & $\begin{array}{r}\text { this general picture (the } \\
\text { theory) suggests certain ideas } \\
\text { which may }\end{array}$ & in & $\begin{array}{l}\text { on-Christians wish to } \\
\text { neir babies undergo a } \\
\text { ony in a }\end{array}$ \\
\hline 13 & $\begin{array}{l}\mathrm{B} 2 \mathrm{G} \\
1233\end{array}$ & $\begin{array}{r}\text { namely, the teaching of } \\
\text { sexual magic, and this } \\
\text { teaching }\end{array}$ & ins & $\begin{array}{l}\text {, without exception, all the } \\
\text { secrets of Nature, all the }\end{array}$ \\
\hline 14 & $\begin{array}{l}\text { B2J } \\
80\end{array}$ & $\begin{array}{r}\text { observed increase in rank up } \\
\text { to the medium-volatile stage } \\
\text { could be adequately }\end{array}$ & & $\begin{array}{l}\text { as the thermal result of former } \\
\text { depth of burial; the higher }\end{array}$ \\
\hline 15 & $\begin{array}{l}\text { B3J } \\
2949\end{array}$ & $\begin{array}{r}\text { 'Nigger flushed, 'I was,' he } \\
\text { replied and }\end{array}$ & & $\begin{array}{l}\text { to Terry the reason for his } \\
\text { incarceration. 'How's your }\end{array}$ \\
\hline 16 & $\begin{array}{l}\text { B7F } \\
58\end{array}$ & $\begin{array}{r}\text { industries die they are usually } \\
\text { operating near to peak } \\
\text { employment, }\end{array}$ & explains & $\begin{array}{l}\text { James Wilson, the } \\
\text { corporation's chief executive. } \\
\text { 'The new }\end{array}$ \\
\hline
\end{tabular}


17

BMG how can the rare cases that 1110 have kept the story going be

$18 \mathrm{BPF} \quad$ in the red? 'Attitudes to

18869 money are important',

19 C8P Catch the bomb Ask the

19753 children to sit in a circle and

$20 \mathrm{CBF} \quad$ we can - as normal as

2012543 possible. 'You can't

CBU to the cost of raising capital

21708 from shareholders. As Mr

Lawrence

22

CCD that she was destined for high

290 places. She could not have

the proposed operating centre

23 CDP was unsuitable on

523 environmental grounds. The

Council

24 CFJ not like the sound of that. 'I

$\begin{array}{rlr}24 & 1286 & \text { mean,' } \\ 25 & \text { CG6 rather than reinforcement by } \\ 131 & \text { adults. While simple imitation }\end{array}$

fails to

26 CGF

one told about the Carib is 413 clearly not adequate: it over

27 CGF the linguistic correlates of

$595 \quad$ most successful in

$28 \mathrm{CH} 2$ of men here or something? 10516 Rita Loumansky, 71,

29 CH5 , ever since Allan Lamb, who

5541 plays for England, bravely

30 CHU oblige. Others, including the

$301159 \quad$ London councils, were sympathetic but

31 CJX than you do. For reasons it

2435 would be too complicated to developed strategies

32 CLE

CLE comprising both labour

$292 \quad$ market and political

components how can we
? The answer seems to be that

explained a female cat sometimes experiences

explains Relate Guide to Better

Relationships,

explain that the aim of the game is to

toss the beanbag (

explain it. You can't tell them there is any logic to

explains , 'it's tilted the balance in favour of borrowing rather

it but she no longer even

explained thought of herself as Joan Halidon

that the operating centre had

explained no relevant planning permission nor had any

explained Anabelle, 'I can't do it all alone. I

explain the occurrence of such nov researchers have what is really a rather small

explains difference. Nevertheless the problem remains sex differences when it looks

explaining very carefully at the conditions of particular

explained :'There are always more women than men here.' to my colleagues what Wasim explained and Whacker - sorry, Waqar explained that it would take months, not hours, to get the

explain to you now, I believe that this may not be a

within the European context

explain the greater emphasis upon the achievement of radical 
33

; and the remark made when I 1088 reported how I had initially because the ethologists are,

$34 \quad \mathrm{CMH}$

35

CN9 leave no doubt that the scale 388 of these changes cannot be 36

CRB 411

of them unsavoury, about his homosexual life in Cuba. Arenas

CRS beginning to interview people in depth, I realised that, to

explain

the absence of a strong

38 CS3 1172

39

CTX in faxes, for example. The 2013 manual is well written and

40 EA2 of 10314 civil servants between 3251985 and 1988 with the aim of

EB2 195

a liberal theory of contract.

Even if this flaw can be

EDH of the whole. According to the 317 functionalist, then, to

of disciplines. So we have an

EDU 274 operatic phenomenon that can be the Criminal Justice Bill

EEC without any provision 585 abolishing capital punishment and to

EER the party a great deal of 387 anxiety over my views' he

the type of phenomenon or the way in which it is being explained my research aims to the union stewards - 'You told the why particular parts of the behaviours like sex by any combination of relative explained adjustments within the context of post-war international that, although he was explained suffering from AIDS when he wrote the this juxtaposition of apparently contradictory values within individuals, I needed to by (a) the 'newness' and apparent 'classlessness explains how the device works, but it doesn't explain how to socioeconomic gradients in explaining morbidity and mortality. In addition to the established away, however, a further

explained examination of the concept of protected the existence of a social explain institution we must not look for purposive in good, old-fashioned explained aesthetic terms. At a time when the

in the Second Reading Debate

explain that since the question of capital punishment and added 'but strangely explained enough with this book it has not . In this chapter, we shall explained describe the phenomenon being explained EFX account of his expenses in a pocket notebook. One friend explained which she was lamenting the
927 p conversation in has cost 
Maja Séguin: Corpus based study of verby explain and clarify as an example of assistance in pedagogical settings

\begin{tabular}{|c|c|c|c|c|}
\hline 48 & $\begin{array}{l}\text { EW7 } \\
159\end{array}$ & $\begin{array}{l}\text { explication is sometimes a } \\
\text { barrier to understanding. } \\
\text { When the concept is }\end{array}$ & explained & $\begin{array}{l}\text { by some writers, educational } \\
\text { technology: ... can best be } \\
\text { viewed }\end{array}$ \\
\hline 49 & $\begin{array}{l}\text { EWR } \\
506\end{array}$ & $\begin{array}{r}\text { its aims and the most } \\
\text { transcendental in its language. } \\
\text { It also }\end{array}$ & exp & $\begin{array}{l}\text { its oscillation between a } \\
\text { concern with shrines and } \\
\text { pilgrimages, with } \\
\text { sanctification }\end{array}$ \\
\hline 50 & $\begin{array}{l}\text { F9W } \\
477\end{array}$ & $\begin{array}{l}\text { the kind discussed in } 2 . \\
\text { Clearly, if we are to }\end{array}$ & explain & $\begin{array}{l}\text { such interpretation we will } \\
\text { need more than our list of } \\
\text { cohesive devices }\end{array}$ \\
\hline 51 & $\begin{array}{l}\text { FP4 } \\
1340\end{array}$ & $\begin{array}{r}\text { characteristics. The residual, } \\
\text { that part of the earnings gap } \\
\text { not }\end{array}$ & & $\begin{array}{l}\text { by pe } \\
\text { conve } \\
\text { indice }\end{array}$ \\
\hline 52 & $\begin{array}{l}\text { FRL } \\
1934\end{array}$ & $\begin{array}{r}\text { preference for negative } \\
\text { additive conjunctions such as } \\
\text { nor. Smith and Frawley }\end{array}$ & e & $\begin{array}{l}\text { this feature by suggesting that } \\
\text { 'the high percentage of } \\
\text { negative additive }\end{array}$ \\
\hline 53 & $\begin{array}{l}\text { FS0 } \\
1431\end{array}$ & $\begin{array}{r}\text { my decision as I understood } \\
\text { his. I didn't have to }\end{array}$ & explain & $\begin{array}{l}\text { le more, while } \\
\text { orepared }\end{array}$ \\
\hline 54 & $\begin{array}{l}\text { FSA } \\
16\end{array}$ & $\begin{array}{r}\text { by the empirical evidence, and } \\
\text { that the earlier underpricing } \\
\text { may be }\end{array}$ & & $\begin{array}{l}\text { by the } \\
\text { and th } \\
\text { partic }\end{array}$ \\
\hline 55 & $\begin{array}{l}\text { FSC } \\
1054\end{array}$ & $\begin{array}{l}\text { Julia denied feeling the least } \\
\text { bit tired and she pressed him }\end{array}$ & ex & $\begin{array}{l}\text { what he meant. 'It is difficult } \\
\text { to justify when you }\end{array}$ \\
\hline 56 & $\begin{array}{l}\text { FSE } \\
285\end{array}$ & $\begin{array}{r}\text { existed between them and } \\
\text { other humans a coldness } \\
\text { which could not be }\end{array}$ & & the \\
\hline 57 & 81 & $\begin{array}{l}\text { catwalk to the otl } \\
\text { prevent suicides,' Nic }\end{array}$ & & $\begin{array}{l}\text { r. 'Are } \\
\text { at suicide }\end{array}$ \\
\hline 58 & $\begin{array}{l}\mathrm{G} 0 \mathrm{H} \\
639\end{array}$ & $\begin{array}{r}\text { Darwin were inspired by Lyell } \\
\text { to look for geological changes } \\
\text { that would }\end{array}$ & e & $\begin{array}{l}\text { ent distribution of } \\
\text { in Europe. But Forbes } \\
\text { ble }\end{array}$ \\
\hline 59 & $\begin{array}{l}\mathrm{GOH} \\
980\end{array}$ & $\begin{array}{r}\text { national responses suggest } \\
\text { that we should be wary of any } \\
\text { attempt to }\end{array}$ & e & $\begin{array}{l}\text { lutionism } \\
\text { jident }\end{array}$ \\
\hline 60 & $\begin{array}{l}\text { G0X } \\
3093\end{array}$ & $\begin{array}{r}\text { Finn. 'That awful girl you took } \\
\text { to Greece, }\end{array}$ & lained & $\begin{array}{l}\text { Lydia. 'Oh, she's around,' said } \\
\text { Finn }\end{array}$ \\
\hline 61 & $\begin{array}{l}\text { G1R } \\
413\end{array}$ & $\begin{array}{r}\text { by the Comintern. This neglect } \\
\text { of the indigenous peasantry } \\
\text { helps to }\end{array}$ & explain & $\begin{array}{l}\text { the appeal of Maoism in Latin } \\
\text { America and the over- } \\
\text { estimation of the }\end{array}$ \\
\hline 62 & $\begin{array}{l}\text { GUF } \\
3582\end{array}$ & $\begin{array}{l}\text { be a strange coupling, but } \\
\text { Frances wouldn't refuse. He }\end{array}$ & t & $\begin{array}{l}\text { to Jacqui about the German } \\
\text { measles. 'Oh no, for }\end{array}$ \\
\hline 63 & $\begin{array}{l}\text { GV8 } \\
3218\end{array}$ & $\begin{array}{l}\text { feeling like - maybe she'd } \\
\text { give a chap a chance to }\end{array}$ & explain & $\begin{array}{l}\text { that there's already a woman } \\
\text { in his flat, a woman }\end{array}$ \\
\hline
\end{tabular}


Maja Séguin: Corpus based study of verby explain and clarify as an example of assistance in pedagogical settings 3715 really given him time to

explain creature prancing about in the hall

65 GVK 335

Brezhnev's plan and they chose their arguments accordingly. One commentator

this good-natured, reputedly

66 GWM 436

moderate drinker merited such treatment has never been

$67 \mathrm{GXJ}$ 1194

members of staff from the

Department of Highways will be present to

\begin{tabular}{|c|c|c|c|}
\hline 68 & $\begin{array}{l}\mathrm{H} 45 \\
194\end{array}$ & $\begin{array}{l}\text { expressive nature. He would } \\
\text { play us a popular classical explaining } \\
\text { piece, }\end{array}$ & $\begin{array}{l}\text { what the compose was trying } \\
\text { to get across to the listener. }\end{array}$ \\
\hline 69 & $\begin{array}{l}\mathrm{H} 86 \\
2618\end{array}$ & $\begin{array}{l}\text { small cigar. 'I'm not being explained } \\
\text { inhospitable,' he }\end{array}$ & $\begin{array}{l}\text {,'but we have to assume the } \\
\text { chance of them having }\end{array}$ \\
\hline 70 & $\begin{array}{l}\mathrm{H} 9 \mathrm{~A} \\
733\end{array}$ & $\begin{array}{r}\text { a short run reputation effect. } \\
\text { The answer to this question explains } \\
\text { also }\end{array}$ & $\begin{array}{l}\text { why the bound derived by } \\
\text { Fudenberg and Levine } \\
\text { continues to hold. }\end{array}$ \\
\hline 71 & $\begin{array}{l}\text { HA4 } \\
1793\end{array}$ & $\begin{array}{l}\text { unromantic cold. 'We were explained } \\
\text { worried about you,' Ianthe }\end{array}$ & $\begin{array}{l}\text {, sitting down on the edge of } \\
\text { the narrow bed. }\end{array}$ \\
\hline 72 & $\begin{array}{l}\text { HGD } \\
756\end{array}$ & $\begin{array}{l}\text { He flushed uneasily. 'What I explained } \\
\text { mean is - she }\end{array}$ & $\begin{array}{l}\text { your circumstances quite } \\
\text { openly and asked that if } \\
\text { anything happened to her }\end{array}$ \\
\hline 73 & $\begin{array}{l}\text { HGR } \\
2474\end{array}$ & $\begin{array}{r}\text { lexicon. However it is unlikely } \\
\text { that a set of rules to }\end{array}$ & $\begin{array}{l}\text { how general language is } \\
\text { processed will be available in } \\
\text { the foreseeable future }\end{array}$ \\
\hline 74 & $\begin{array}{l}\mathrm{HH} 2 \\
805\end{array}$ & $\begin{array}{l}\text { resources. The object of the } \\
\text { analysis is then to identify and }\end{array}$ & $\begin{array}{l}\text { in what circumstances the } \\
\text { authoritarian direction of } \\
\text { resources has advantage over } \\
\text { market-type }\end{array}$ \\
\hline 75 & $\begin{array}{l}\mathrm{HH} 3 \\
1277\end{array}$ & $\begin{array}{l}\text { The violent eruption which } \\
\text { killed } 1,700 \text { people has never explained } \\
\text { been satisfactorily }\end{array}$ & $\begin{array}{l}\text { The official version, blaming } \\
\text { the disaster on natural causes, }\end{array}$ \\
\hline 76 & $\begin{array}{l}\text { HHA } \\
1404\end{array}$ & $\begin{array}{r}\text {.'I've just remembered ... just explained } \\
\text { realised,' she }\end{array}$ & $\begin{array}{l}\text { 'So you really are Caro's } \\
\text { stepbrother.' ' }\end{array}$ \\
\hline 77 & $\begin{array}{l}\text { HHF } \\
200\end{array}$ & $\begin{array}{l}\text { than filled, the more usual and explained } \\
\text { cheaper method. A farmer }\end{array}$ & $\begin{array}{l}\text { that the area is subjected to } \\
\text { floods sometimes, and it was }\end{array}$ \\
\hline 78 & $\begin{array}{l}\mathrm{HHV} \\
17276\end{array}$ & $\begin{array}{l}\text { We will fight them. Mr. } \\
\text { Geraint Howells Can the explain } \\
\text { Minister }\end{array}$ & $\begin{array}{l}\text { why } 10,000 \text { full-time farmers } \\
\text { left the land last year? There is }\end{array}$ \\
\hline 79 & $\begin{array}{l}\text { HJ3 } \\
5625\end{array}$ & $\begin{array}{l}\text { by a load of Job's Comforters ex } \\
\text { telling you their troubles and }\end{array}$ & $\begin{array}{l}\text { how hard } \\
\text { be. Seek }\end{array}$ \\
\hline
\end{tabular}

Curtis Price asks: 'would Purcell have poked such cruel the new road proposals in the explain Westburn/Baberton area. The Council would

that this plan would enable
explained the Persian Gulf states 'to choose

\begin{tabular}{|c|c|}
\hline explained & $\begin{array}{l}\text {. Curtis Price asks: 'would } \\
\text { Purcell have poked such cruel }\end{array}$ \\
\hline explain & $\begin{array}{l}\text { Westburn/Baberton area. The } \\
\text { Council would }\end{array}$ \\
\hline
\end{tabular}

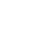




\begin{tabular}{|c|c|c|c|c|}
\hline 80 & $\begin{array}{l}\text { HLY } \\
47\end{array}$ & $\begin{array}{r}\text { er, the new European directive } \\
\text { almost ruined his holiday } \\
\text { [pause] he then }\end{array}$ & $d$ & $\begin{array}{l}\text { [pause] he booked up to take } \\
\text { his family to EuroDisney. On } \\
\text { his }\end{array}$ \\
\hline 8 & $\begin{array}{l}\mathrm{HPB} \\
114\end{array}$ & $\begin{array}{r}\text { the day. 'We did a lot of } \\
\text { leafleting,' }\end{array}$ & lained & $\begin{array}{l}\text { Alex. 'I was outside the hall } \\
\text { leafleting when the debate }\end{array}$ \\
\hline 82 & $\begin{array}{l}\text { HS7 } \\
159\end{array}$ & $\begin{array}{l}\text { And so the catechist who talks } \\
\text { but does not relate, who }\end{array}$ & explains & $\begin{array}{l}\text { but does not feel is faced with } \\
\text { a handicapped person like the }\end{array}$ \\
\hline 83 & $\begin{array}{l}\text { HSA } \\
684\end{array}$ & $\begin{array}{r}\text { repeated between sips. The } \\
\text { custom of cleaning the close } \\
\text { had been }\end{array}$ & & $\begin{array}{l}\text { to Madg } \\
\text { moved } i\end{array}$ \\
\hline 84 & 90 & $\begin{array}{l}\text { surprise. They don't know } \\
\text { we're here,' she }\end{array}$ & & $\begin{array}{l}\mathrm{He} \\
\text { glar }\end{array}$ \\
\hline 85 & $\begin{array}{l}\text { HU2 } \\
5230\end{array}$ & $\begin{array}{r}\text { metabolic effect of the } \\
\text { tumours, how can such a } \\
\text { phenomenon be }\end{array}$ & & $\begin{array}{l}\text { nsideration of the } \\
\text { that bile } \\
\text { ts and their } \\
\text { ic }\end{array}$ \\
\hline 86 & $\begin{array}{l}\text { HWF } \\
6867\end{array}$ & $\begin{array}{r}\text { Interface for LIFH } \\
\text { manual ha } \\
\text { o }\end{array}$ & & $\begin{array}{l}\text { begins } \\
\text { J. To }\end{array}$ \\
\hline 87 & $\begin{array}{l}\mathrm{HX} 4 \\
551\end{array}$ & $\begin{array}{r}\text {, and franchiser companies to } \\
\text { grow more rapidly, as Burger } \\
\text { King }\end{array}$ & & fast \\
\hline 88 & $\begin{array}{l}\mathrm{HX9} \\
112\end{array}$ & $\begin{array}{r}\text { and bottom-up inform } \\
\text { given the experimental re } \\
\text { We are a }\end{array}$ & & d \\
\hline 8 & $\begin{array}{l}\text { JTE } \\
322\end{array}$ & $\begin{array}{r}\text { Germany. And } \\
\text { the ba }\end{array}$ & explain & e go \\
\hline 9 & $\begin{array}{l}\text { JY0 } \\
56\end{array}$ & not - Juliet be & explain & ised, hadn't she? \\
\hline 91 & $\begin{array}{l}\text { K1D } \\
1987\end{array}$ & $\begin{array}{r}\text { Voice over Fo } \\
\text { visit was }\end{array}$ & xplain & $w$ \\
\hline 92 & $\begin{array}{l}\text { K55 } \\
1368\end{array}$ & $\begin{array}{r}\text { the town centre. Mr Milburn } \\
\text { has contacted Durham County } \\
\text { Council to }\end{array}$ & & $\begin{array}{l}\text { d push the case } \\
\text { ple in the }\end{array}$ \\
\hline 93 & $\begin{array}{l}\text { K55 } \\
9399\end{array}$ & $\begin{array}{r}\text { RAF Leuchars in Scotlan } \\
\text { raced to the sce } \\
\text { spoke }\end{array}$ & & $\begin{array}{l}\text { : 'The } \\
\text { becau }\end{array}$ \\
\hline 94 & $\begin{array}{l}\text { K5L } \\
1683\end{array}$ & $\begin{array}{r}\text { per cent a year for the last five } \\
\text { years. How to }\end{array}$ & ain & $\begin{array}{l}\text { ttack the } \\
\text { American }\end{array}$ \\
\hline 95 & $\begin{array}{l}\text { K5P } \\
411\end{array}$ & $\begin{array}{r}\text { the dissociation becomes } \\
\text { slower at higher occupancy. } \\
\text { This is difficult to }\end{array}$ & $\exp$ & $\begin{array}{l}\text { since when a fully saturated } \\
\text { complex is half dissociated it } \\
\text { will have }\end{array}$ \\
\hline & 336 & coming today, as I & & $\begin{array}{l}\text { on the telephone to you } \mathrm{Mhm} \text {. } \\
\text { is twofold really, one }\end{array}$ \\
\hline
\end{tabular}


Maja Séguin: Corpus based study of verby explain and clarify as an example of assistance in pedagogical settings

\begin{tabular}{|c|c|c|c|c|}
\hline 97 & $\begin{array}{l}\text { K93 } \\
1326\end{array}$ & $\begin{array}{r}\text { last chapter the structure of } \\
\text { the tone-unit was introduced } \\
\text { and it was }\end{array}$ & $\exp$ & $\begin{array}{l}\text { that when a ton } \\
\text { followed by a t }\end{array}$ \\
\hline 98 & $\begin{array}{l}\text { K93 } \\
1696\end{array}$ & $\begin{array}{r}\text { clear that studying intonation } \\
\text { in relation to discourse makes } \\
\text { it possible to }\end{array}$ & in & $\begin{array}{l}\text { ensively } \\
\text { s make of } \\
y\end{array}$ \\
\hline 99 & $\begin{array}{l}\text { KLG } \\
184\end{array}$ & $\begin{array}{r}\text { Erm Probably a little bit } \\
\text { certainly Mm. ea }\end{array}$ & explain & ok at cos \\
\hline 1 & $\begin{array}{l}\mathrm{KPW} \\
3\end{array}$ & $\begin{array}{l}\text {, you don't understand, you } \\
\text { see I [unclear] Well, }\end{array}$ & explain & $\begin{array}{l}\text { it then? You're so stupid! Go } \\
\text { on, Charlotte }\end{array}$ \\
\hline
\end{tabular}




\section{Appendix 3: Quoted speech in 100-line sample for '\{explain/ V\}'}

Table 18: Quoted speech, explain

\begin{tabular}{|c|c|c|c|}
\hline & $\begin{array}{l}\text { ACK } \\
1545\end{array}$ & $\begin{array}{r}\text { well. 'I'm used to Nigel now,' } \\
\text { Elinor }\end{array}$ & $\begin{array}{l}\text { to me, 'but it's nice to have a } \\
\text { change }\end{array}$ \\
\hline & $\begin{array}{l}\text { ADR } \\
1482\end{array}$ & $\begin{array}{l}\text { sex symbol was the Sydney } \\
\text { fashion guru. Nicole Bonython. explained } \\
\text { She }\end{array}$ & $\begin{array}{l}\text { : 'I was called in at the last } \\
\text { minute to help }\end{array}$ \\
\hline 6 & $\begin{array}{l}\text { AEA } \\
1221\end{array}$ & $\begin{array}{r}\text { adore.' 'I don't feel that you're explaining } \\
\text { really }\end{array}$ & $\begin{array}{l}\text { yourself. I don't really } \\
\text { understand. You love it here }\end{array}$ \\
\hline 8 & $\begin{array}{l}\text { AM6 } \\
481\end{array}$ & $\begin{array}{l}\text { have in common is the } \\
\text { requirement of 'aesthetic explains } \\
\text { intention', }\end{array}$ & $\begin{array}{l}: \text { For - cutting straight } \\
\text { through the recurring } \\
\text { controversies about whether, }\end{array}$ \\
\hline & $\begin{array}{l}\text { B3J } \\
2949\end{array}$ & $\begin{array}{r}\text { ' Nigger flushed, 'I was,' he } \\
\text { replied and }\end{array}$ & $\begin{array}{l}\text { to Terry the reason for his } \\
\text { incarceration. 'How's your }\end{array}$ \\
\hline 16 & $\begin{array}{l}\text { B7F } \\
58\end{array}$ & $\begin{array}{l}\text { industries die they are usually } \\
\text { operating near to peak explains } \\
\text { employment, }\end{array}$ & $\begin{array}{l}\text { James Wilson, the } \\
\text { corporation's chief executive. } \\
\text { 'The new }\end{array}$ \\
\hline 18 & $\begin{array}{l}\mathrm{BPF} \\
869\end{array}$ & $\begin{array}{l}\text { in the red? 'Attitudes to money explains } \\
\text { are important', }\end{array}$ & $\begin{array}{l}\text { Sarah Litvinoff, author of The } \\
\text { Relate Guide to Better } \\
\text { Relationships, }\end{array}$ \\
\hline 20 & $\begin{array}{l}\text { CBF } \\
12543\end{array}$ & $\begin{array}{l}\text { we can - as normal as } \\
\text { possible. 'You can't explain }\end{array}$ & $\begin{array}{l}\text { it. You can't tell them there is } \\
\text { any logic to }\end{array}$ \\
\hline 21 & $\begin{array}{l}\text { CBU } \\
708\end{array}$ & $\begin{array}{l}\text { to the cost of raising capital } \\
\text { from shareholders. As } \mathrm{Mr} \text { explains } \\
\text { Lawrence }\end{array}$ & $\begin{array}{l}\text {,'it's tilted the balance in } \\
\text { favour of borrowing rather }\end{array}$ \\
\hline 24 & $\begin{array}{l}\text { CFJ } \\
1286\end{array}$ & $\begin{array}{r}\text { not like the sound of that. 'I } \\
\text { mean,' expl }\end{array}$ & $\begin{array}{l}\text { Anabelle, 'I can't do it all } \\
\text { alone. I }\end{array}$ \\
\hline 28 & $\begin{array}{l}\mathrm{CH} 2 \\
10516\end{array}$ & $\begin{array}{l}\text { of men here or something?' } \\
\text { Rita Loumansky, } 71,\end{array}$ & $\begin{array}{l}\text { :'There are always more } \\
\text { women than men here.' }\end{array}$ \\
\hline 45 & $\begin{array}{l}\text { EER } \\
387\end{array}$ & $\begin{array}{l}\text { the party a great deal of } \\
\text { anxiety over my views' he }\end{array}$ & $\begin{array}{l}\text { and added 'but strangely } \\
\text { enough with this book it has } \\
\text { not }\end{array}$ \\
\hline 57 & $\begin{array}{l}\text { G01 } \\
598\end{array}$ & $\begin{array}{l}\text { catwalk to the other. 'To } \\
\text { prevent suicides,' Nicholson }\end{array}$ & $\begin{array}{l}\text {, standing beside her. 'Are } \\
\text { there many attempts at } \\
\text { suicide }\end{array}$ \\
\hline 60 & $\begin{array}{l}\text { G0X } \\
3093\end{array}$ & $\begin{array}{r}\text { Finn. 'That awful girl you took } \\
\text { to Greece,' }\end{array}$ & $\begin{array}{l}\text { Lydia. 'Oh, she's around,' said } \\
\text { Finn }\end{array}$ \\
\hline 62 & $\begin{array}{l}\text { GUF } \\
3582\end{array}$ & $\begin{array}{l}\text { be a strange coupling, but } \\
\text { Frances wouldn't refuse. He }\end{array}$ & $\begin{array}{l}\text { to Jacqui about the German } \\
\text { measles. 'Oh no, for }\end{array}$ \\
\hline 69 & $\begin{array}{l}\text { H86 } \\
2618\end{array}$ & $\begin{array}{l}\text { small cigar. 'I'm not being } \\
\text { inhospitable,' he explained }\end{array}$ & $\begin{array}{l}\text { ' but we have to assume the } \\
\text { chance of them having }\end{array}$ \\
\hline & $\begin{array}{l}\text { HA4 } \\
1793\end{array}$ & $\begin{array}{l}\text { unromantic cold. 'We were explained } \\
\text { worried about you,' Ianthe }\end{array}$ & $\begin{array}{l}\text {, sitting down on the edge of } \\
\text { the narrow bed.' }\end{array}$ \\
\hline
\end{tabular}


Maja Séguin: Corpus based study of verby explain and clarify as an example of assistance in pedagogical settings

\begin{tabular}{|c|c|c|c|}
\hline 72 & $\begin{array}{l}\text { HGD } \\
756\end{array}$ & $\begin{array}{l}\text { He flushed uneasily. 'What I explained } \\
\text { mean is - she }\end{array}$ & $\begin{array}{l}\text { your circumstances quite } \\
\text { openly and asked that if } \\
\text { anything happened to her }\end{array}$ \\
\hline 76 & $\begin{array}{l}\text { HHA } \\
1404\end{array}$ & $\begin{array}{r}\text {.'I've just remembered ... just explained } \\
\text { realised,' she }\end{array}$ & $\begin{array}{l}\text { 'So you really are Caro's } \\
\text { stepbrother.' ' }\end{array}$ \\
\hline 81 & $\begin{array}{l}\text { HPB } \\
114\end{array}$ & $\begin{array}{r}\text { the day. 'We did a lot of } \\
\text { leafleting,' explained }\end{array}$ & $\begin{array}{l}\text { Alex. 'I was outside the hall } \\
\text { leafleting when the debate }\end{array}$ \\
\hline 84 & $\begin{array}{l}\text { HTH } \\
1190\end{array}$ & $\begin{array}{l}\text { surprise. They don't know explained } \\
\text { we're here,' she }\end{array}$ & $\begin{array}{l}\text { He gave her a sidelong } \\
\text { glance. 'You've been }\end{array}$ \\
\hline 90 & JY0 56 & $\begin{array}{r}\text { not }- \text { ' Juliet began. But she } \\
\text { didn't have to explain }\end{array}$ & $\begin{array}{l}\text {.She'd apologised, hadn't she? } \\
\text { She twisted out }\end{array}$ \\
\hline 93 & $\begin{array}{l}\text { K55 } \\
9399\end{array}$ & $\begin{array}{l}\text { RAF Leuchars in Scotland also } \\
\text { raced to the scene. A explained } \\
\text { spokesman }\end{array}$ & $\begin{array}{l}\text { :'They are being called in } \\
\text { because visibility is so bad }\end{array}$ \\
\hline
\end{tabular}




\section{Appendix 4: Collocates close to explain, per colligate im- mediately following explain}

The following tables represent the top 15 collocates which follow (range R1 R4) or precede (L5 - L1) the verb. Although the range depends on where the topic being clarified is considered likely from analysis of the sample, in all cases the minimum frequency (both 'node,collocate' an 'collocate') are set to be at least 5 . The collocates are based on the results found for the verb explain followed by the chosen colligate.

Table 19: Collocates ranked by log-likelihood following $\{$ explain/V\}_AT0

\begin{tabular}{|l|l|l|l|l|l|l|}
\hline No & Lemma & $\begin{array}{l}\text { Total } \\
\text { No. in } \\
\text { whole } \\
\text { BNC }\end{array}$ & $\begin{array}{l}\text { Expected } \\
\text { collocate } \\
\text { frequency }\end{array}$ & $\begin{array}{l}\text { Observed } \\
\text { collocate } \\
\text { frequency }\end{array}$ & $\begin{array}{l}\text { In } \\
\text { No. } \\
\text { of } \\
\text { texts }\end{array}$ & $\begin{array}{l}\text { Log- } \\
\text { likelihood } \\
\text { value }\end{array}$ \\
\hline 1 & the_ART & $6,040,293$ & 634.514 & 3185 & 1271 & 5811.5261 \\
\hline 2 & of_PREP & $3,040,508$ & 319.396 & 1140 & 657 & 1320.2158 \\
\hline 3 & situation_SUBST & 19,544 & 2.053 & 64 & 62 & 316.8933 \\
\hline 4 & nature_SUBST & 17,880 & 1.878 & 56 & 47 & 272.4116 \\
\hline 5 & difference_SUBST & 18,887 & 1.984 & 55 & 49 & 259.799 \\
\hline 6 & reason_SUBST & 28,549 & 2.999 & 59 & 55 & 239.9279 \\
\hline 7 & phenomenon_SUBST & 3,451 & 0.363 & 32 & 27 & 223.848 \\
\hline 8 & between_PREP & 90,191 & 9.474 & 70 & 65 & 159.2891 \\
\hline 9 & origin_SUBST & 4,697 & 0.493 & 25 & 23 & 147.431 \\
\hline 10 & behaviour_SUBST & 12,676 & 1.332 & 31 & 26 & 135.9602 \\
\hline 11 & meaning_SUBST & 7,904 & 0.830 & 27 & 19 & 135.8236 \\
\hline 12 & behind_PREP & 19,056 & 2.002 & 31 & 31 & 111.9963 \\
\hline 13 & observed_ADJ & 480 & 0.050 & 12 & 10 & 107.7464 \\
\hline 14 & procedure_SUBST & 11,024 & 1.158 & 25 & 20 & 106.0235 \\
\hline 15 & apparent_ADJ & 5,208 & 0.547 & 20 & 18 & 105.1545 \\
\hline
\end{tabular}

Table 20: Collocates ranked by mutual information following \{explain/V\} _AT0

\begin{tabular}{|l|l|l|l|l|l|l|}
\hline No. & Lemma & $\begin{array}{l}\text { Total } \\
\text { No. in } \\
\text { whole } \\
\text { BNC }\end{array}$ & $\begin{array}{l}\text { Expected } \\
\text { collocate } \\
\text { frequency }\end{array}$ & $\begin{array}{l}\text { Observed } \\
\text { collocate } \\
\text { frequency }\end{array}$ & $\begin{array}{l}\text { In No. } \\
\text { of } \\
\text { texts }\end{array}$ & $\begin{array}{l}\text { Mutual } \\
\text { informa- } \\
\text { tion value }\end{array}$ \\
\hline 1 & flypaper_SUBST & 14 & 0.001 & 5 & 1 & 11.7313 \\
\hline 2 & puzzling_ADJ & 196 & 0.021 & 7 & 7 & 8.4093 \\
\hline 3 & observed_ADJ & 480 & 0.050 & 12 & 10 & 7.8948 \\
\hline 4 & persistence_SUBST & 460 & 0.048 & 8 & 8 & 7.3712 \\
\hline 5 & rationale_SUBST & 583 & 0.061 & 9 & 9 & 7.1993 \\
\hline 6 & cross-section_SUBST & 333 & 0.035 & 5 & 2 & 7.1592 \\
\hline
\end{tabular}


Maja Séguin: Corpus based study of verby explain and clarify as an example of assistance in pedagogical settings

\begin{tabular}{|c|l|l|l|l|l|l|}
\hline 7 & discrepancy_SUBST & 650 & 0.068 & 7 & 7 & 6.6797 \\
\hline 8 & phenomenon_SUBST & 3,451 & 0.363 & 32 & 27 & 6.4639 \\
\hline 9 & paradox_SUBST & 763 & 0.080 & 5 & 5 & 5.9631 \\
\hline 10 & emergence_SUBST & 1,231 & 0.129 & 8 & 7 & 5.9511 \\
\hline 11 & reluctance_SUBST & 1,013 & 0.106 & 6 & 6 & 5.8172 \\
\hline 12 & origin_SUBST & 4,697 & 0.493 & 25 & 23 & 5.663 \\
\hline 13 & reasoning_SUBST & 952 & 0.100 & 5 & 5 & 5.6438 \\
\hline 14 & Occurrence_SUBST & 1,343 & 0.141 & 7 & 6 & 5.6328 \\
\hline 15 & incidence_SUBST & 1,761 & 0.185 & 8 & 8 & 5.4345 \\
\hline
\end{tabular}

Table 21: Collocates ranked by log-likelihood following \{explain/V\}_AVQ

\begin{tabular}{|l|l|l|l|l|l|l|}
\hline No. & Lemma & $\begin{array}{l}\text { Total No. } \\
\text { in whole } \\
\text { BNC }\end{array}$ & $\begin{array}{l}\text { Expected } \\
\text { collocate } \\
\text { frequency }\end{array}$ & $\begin{array}{l}\text { Observed } \\
\text { collocate } \\
\text { frequency }\end{array}$ & $\begin{array}{l}\text { In } \\
\text { No. } \\
\text { of } \\
\text { texts }\end{array}$ & $\begin{array}{l}\text { Log- } \\
\text { likelihood } \\
\text { value }\end{array}$ \\
\hline 1 & why_ADV & 48,563 & 4.058 & 1475 & 860 & 14739.5718 \\
\hline 2 & how_ADV & 98,967 & 8.270 & 889 & 567 & 6648.4717 \\
\hline 3 & he_PRON & $1,198,025$ & 100.115 & 213 & 173 & 97.2402 \\
\hline 4 & should_VERB & 108,970 & 9.106 & 48 & 44 & 81.9634 \\
\hline 5 & come_VERB & 144,726 & 12.094 & 54 & 49 & 77.9841 \\
\hline 6 & it_PRON & $1,213,293$ & 101.391 & 196 & 172 & 70.1384 \\
\hline 7 & have_VERB & $1,316,636$ & 110.027 & 199 & 174 & 58.7649 \\
\hline 8 & so_ADV & 214,145 & 17.895 & 59 & 57 & 58.7532 \\
\hline 9 & work_VERB & 62,972 & 5.262 & 29 & 27 & 51.5835 \\
\hline 10 & be_VERB & $4,119,764$ & 344.274 & 473 & 382 & 44.9011 \\
\hline 11 & they_PRON & 842,089 & 70.370 & 133 & 121 & 44.4976 \\
\hline 12 & choose_VERB & 16,437 & 1.374 & 14 & 11 & 39.7797 \\
\hline 13 & can_VERB & 261,805 & 21.878 & 57 & 53 & 39.0554 \\
\hline 14 & particular_ADJ & 28,628 & 2.392 & 17 & 16 & 37.4869 \\
\hline 15 & woman_SUBST & 60,149 & 5.026 & 24 & 20 & 37.1377 \\
\hline
\end{tabular}

Table 22: collocates ranked by mutual information following \{explain/V\} _AVQ

\begin{tabular}{|l|l|l|l|l|l|l|}
\hline $\begin{array}{l}\text { N } \\
\text { o. }\end{array}$ & Lemma & $\begin{array}{l}\text { Total } \\
\text { No. in } \\
\text { whole } \\
\text { BNC }\end{array}$ & $\begin{array}{l}\text { Expected } \\
\text { collocate } \\
\text { frequency }\end{array}$ & $\begin{array}{l}\text { Observed } \\
\text { collocate } \\
\text { frequency }\end{array}$ & $\begin{array}{l}\text { In No. } \\
\text { of } \\
\text { texts }\end{array}$ & $\begin{array}{l}\text { Mutual } \\
\text { informa- } \\
\text { tion value }\end{array}$ \\
\hline 1 & why_ADV & 48,563 & 4.058 & 1475 & 860 & 8.5056 \\
\hline 2 & how_ADV & 98,967 & 8.270 & 889 & 567 & 6.7481 \\
\hline 3 & universe_SUBST & 2,582 & 0.216 & 6 & 3 & 4.7974 \\
\hline 4 & lifespan_SUBST & 3,729 & 0.312 & 7 & 1 & 4.4895 \\
\hline 5 & cope_VERB & 5,029 & 0.420 & 5 & 4 & 3.5726 \\
\hline 6 & choose_VERB & 16,437 & 1.374 & 14 & 11 & 3.3494 \\
\hline
\end{tabular}


Maja Séguin: Corpus based study of verby explain and clarify as an example of assistance in pedagogical settings

\begin{tabular}{|l|l|l|l|l|l|l|}
\hline 7 & works_SUBST & 7,958 & 0.665 & 6 & 6 & 3.1735 \\
\hline 8 & occur_VERB & 15,430 & 1.289 & 10 & 9 & 2.9552 \\
\hline 9 & individual_SUBST & 13,365 & 1.117 & 8 & 8 & 2.8405 \\
\hline 10 & particular_ADJ & 28,628 & 2.392 & 17 & 16 & 2.829 \\
\hline 11 & operate_VERB & 10,162 & 0.849 & 6 & 6 & 2.8208 \\
\hline 12 & object_SUBST & 9,571 & 0.800 & 5 & 4 & 2.6442 \\
\hline 13 & manage_VERB & 12,775 & 1.068 & 6 & 6 & 2.4906 \\
\hline 14 & work_VERB & 62,972 & 5.262 & 29 & 27 & 2.4623 \\
\hline 15 & should_VERB & $\begin{array}{l}108,97 \\
0\end{array}$ & 9.106 & 48 & 44 & 2.3981 \\
& & & & & & \\
\hline
\end{tabular}

Table 23: collocates ranked by log-likelihood following \{explain/V\}_CJT

\begin{tabular}{|l|l|l|l|l|l|l|}
\hline No. & Lemma & $\begin{array}{l}\text { Total No. } \\
\text { in whole } \\
\text { BNC }\end{array}$ & $\begin{array}{l}\text { Expected } \\
\text { collocate } \\
\text { frequency }\end{array}$ & $\begin{array}{l}\text { Observed } \\
\text { collocate } \\
\text { frequency }\end{array}$ & $\begin{array}{l}\text { In } \\
\text { No. } \\
\text { of } \\
\text { texts }\end{array}$ & $\begin{array}{l}\text { Log- } \\
\text { likelihood } \\
\text { value }\end{array}$ \\
\hline 1 & that_CONJ & 740,455 & 34.743 & 1321 & 776 & 7388.1286 \\
\hline 2 & have_VERB & $1,316,636$ & 61.778 & 217 & 182 & 239.5101 \\
\hline 3 & he_PRON & $1,198,025$ & 56.213 & 188 & 160 & 193.7491 \\
\hline 4 & be_VERB & $4,119,764$ & 193.305 & 403 & 330 & 181.5635 \\
\hline 5 & she_PRON & 654,356 & 30.703 & 79 & 74 & 53.1799 \\
\hline 6 & would_VERB & 278,523 & 13.069 & 45 & 42 & 47.6156 \\
\hline 7 & although_CONJ & 42,701 & 2.004 & 17 & 17 & 42.7565 \\
\hline 8 & this_ADJ & 452,756 & 21.244 & 55 & 55 & 37.3471 \\
\hline 9 & not_ADV & 767,448 & 36.010 & 71 & 67 & 26.6584 \\
\hline 10 & there_PRON & 245,770 & 11.532 & 33 & 31 & 26.5455 \\
\hline 11 & they_PRON & 842,089 & 39.512 & 72 & 63 & 21.6367 \\
\hline 12 & it_PRON & $1,213,293$ & 56.929 & 88 & 83 & 14.6979 \\
\hline 13 & need_VERB & 64,349 & 3.019 & 11 & 11 & 12.4946 \\
\hline 14 & only_ADV & 126,118 & 5.918 & 16 & 16 & 11.6843 \\
\hline 15 & no_ART & 140,366 & 6.586 & 17 & 16 & 11.434 \\
\hline
\end{tabular}

Table 24: Collocates ranked by mutual information following \{explain/V\} -CJT

\begin{tabular}{|l|l|l|l|l|l|l|}
\hline No. & Lemma & $\begin{array}{l}\text { Total No. } \\
\text { in whole } \\
\text { BNC }\end{array}$ & $\begin{array}{l}\text { Expected } \\
\text { collocate } \\
\text { frequency }\end{array}$ & $\begin{array}{l}\text { Observed } \\
\text { collocate } \\
\text { frequency }\end{array}$ & $\begin{array}{l}\text { In } \\
\text { No. } \\
\text { of } \\
\text { texts }\end{array}$ & $\begin{array}{l}\text { Mutual } \\
\text { information } \\
\text { value }\end{array}$ \\
\hline 1 & that_CONJ & 740,455 & 34.743 & 1321 & 776 & 5.2488 \\
\hline 2 & although_CONJ & 42,701 & 2.004 & 17 & 17 & 3.0849 \\
\hline 3 & meeting_SUBST & 21,209 & 0.995 & 5 & 5 & 2.3289 \\
\hline 4 & reason_SUBST & 28,549 & 1.340 & 6 & 6 & 2.1632 \\
\hline 5 & since_CONJ & 28,653 & 1.344 & 5 & 5 & 1.8949 \\
\hline 6 & need_VERB & 64,349 & 3.019 & 11 & 11 & 1.8652 \\
\hline
\end{tabular}


Maja Séguin: Corpus based study of verby explain and clarify as an example of assistance in pedagogical settings

\begin{tabular}{|l|l|l|l|l|l|l|}
\hline 7 & never_ADV & 53,143 & 2.494 & 9 & 8 & 1.8517 \\
\hline 8 & have_VERB & $1,316,636$ & 61.778 & 217 & 182 & 1.8125 \\
\hline 9 & would_VERB & 278,523 & 13.069 & 45 & 42 & 1.7838 \\
\hline 10 & must_VERB & 69,754 & 3.273 & 11 & 10 & 1.7488 \\
\hline 11 & he_PRON & $1,198,025$ & 56.213 & 188 & 160 & 1.7418 \\
\hline 12 & live_VERB & 31,923 & 1.498 & 5 & 5 & 1.739 \\
\hline 13 & already_ADV & 33,223 & 1.559 & 5 & 5 & 1.6814 \\
\hline 14 & there_PRON & 245,770 & 11.532 & 33 & 31 & 1.5168 \\
\hline 15 & only_ADV & 126,118 & 5.918 & 16 & 16 & 1.435 \\
\hline
\end{tabular}

Table 25: Collocates ranked by log-likelihood preceding \{explain/V\}_PRP

\begin{tabular}{|l|l|l|l|l|l|l|}
\hline No. & Lemma & $\begin{array}{l}\text { Total } \\
\text { No. in } \\
\text { whole } \\
\text { BNC }\end{array}$ & $\begin{array}{l}\text { Expected } \\
\text { collocate } \\
\text { frequency }\end{array}$ & $\begin{array}{l}\text { Observed } \\
\text { collocate } \\
\text { frequen- } \\
\text { cy }\end{array}$ & $\begin{array}{l}\text { In No. } \\
\text { of } \\
\text { texts }\end{array}$ & $\begin{array}{l}\text { Log- } \\
\text { likeli- } \\
\text { hood } \\
\text { value }\end{array}$ \\
\hline 1 & be_VERB & $4,119,764$ & 426.888 & 1428 & 723 & 1539.0401 \\
\hline 2 & can_VERB & 261,805 & 27.128 & 336 & 239 & 1082.0428 \\
\hline 3 & could_VERB & 159,818 & 16.560 & 144 & 122 & 369.5159 \\
\hline 4 & as_CONJ & 378,061 & 39.175 & 199 & 154 & 329.4942 \\
\hline 5 & partly_ADV & 5,574 & 0.578 & 42 & 35 & 277.6848 \\
\hline 6 & best_ADV & 7,924 & 0.821 & 39 & 35 & 225.0862 \\
\hline 7 & try_VERB & 52,838 & 5.475 & 64 & 59 & 198.0217 \\
\hline 8 & this_ADJ & 452,756 & 46.914 & 162 & 131 & 172.5308 \\
\hline 9 & may_VERB & 112,405 & 11.647 & 74 & 56 & 149.3148 \\
\hline 10 & i_PRON & $1,128,916$ & 116.978 & 269 & 204 & 146.0021 \\
\hline 11 & to_PREP & $2,593,462$ & 268.734 & 473 & 365 & 130.0277 \\
\hline 12 & fully_ADV & 8,788 & 0.911 & 26 & 25 & 124.2375 \\
\hline 13 & not_ADV & 767,448 & 79.523 & 185 & 147 & 102.4233 \\
\hline 14 & phenomenon_SUBST & 3,451 & 0.358 & 17 & 12 & 98.1131 \\
\hline 15 & will_VERB & 328,997 & 34.091 & 99 & 77 & 81.6462 \\
\hline
\end{tabular}


Maja Séguin: Corpus based study of verby explain and clarify as an example of assistance in pedagogical settings

Table 26: Collocates ranked by mutual information preceding \{explain/V\} PR

\begin{tabular}{|l|l|r|r|r|r|c|}
\hline No. & Lemma & $\begin{array}{c}\text { Total } \\
\text { No. } \\
\text { in } \\
\text { whole } \\
\text { BNC }\end{array}$ & $\begin{array}{c}\text { Expected } \\
\text { collocate } \\
\text { frequency }\end{array}$ & $\begin{array}{c}\text { Observed } \\
\text { collocate } \\
\text { frequency }\end{array}$ & $\begin{array}{c}\text { In } \\
\text { No. } \\
\text { of } \\
\text { texts }\end{array}$ & $\begin{array}{c}\text { Mutual } \\
\text { information } \\
\text { value }\end{array}$ \\
\hline 1 & satisfactorily_ADV & 541 & 0.056 & 8 & 6 & 7.1569 \\
\hline 2 & patiently_ADV & 497 & 0.051 & 5 & 5 & 6.6012 \\
\hline 3 & discrepancy_SUBST & 650 & 0.067 & 6 & 5 & 6.4771 \\
\hline 4 & variance_SUBST & 697 & 0.072 & 6 & 3 & 6.3764 \\
\hline 5 & gastrin_SUBST & 600 & 0.062 & 5 & 4 & 6.3295 \\
\hline 6 & partly_ADV & 5,574 & 0.578 & 42 & 35 & 6.1842 \\
\hline 7 & partially_ADV & 1,284 & 0.133 & 7 & 7 & 5.7173 \\
\hline 8 & adequately_ADV & 1,134 & 0.118 & 6 & 6 & 5.6742 \\
\hline 9 & phenomenon_SUBST & 3,451 & 0.358 & 17 & 12 & 5.5711 \\
\hline 10 & best_ADV & 7,924 & 0.821 & 39 & 35 & 5.5698 \\
\hline 11 & yield_SUBST & 1,637 & 0.170 & 6 & 2 & 5.1445 \\
\hline 12 & readily_ADV & 2,772 & 0.287 & 10 & 8 & 5.1216 \\
\hline 13 & fully_ADV & 8,788 & 0.911 & 26 & 25 & 4.8355 \\
\hline 14 & easily_ADV & 9,625 & 0.997 & 17 & 17 & 4.0913 \\
\hline 15 & curve_SUBST & 3,288 & 0.341 & 5 & 1 & 3.8753 \\
\hline
\end{tabular}

